Check for updates

Cite this: RSC Adv., 2019, 9, 40708

Received 1st November 2019 Accepted 26th November 2019

DOI: $10.1039 / c 9 r a 09047 a$

rsc.li/rsc-advances

\section{Structural, mechanical, spectroscopic and thermodynamic characterization of the copper- uranyl tetrahydroxide mineral vandenbrandeite $\uparrow$}

\author{
Francisco Colmenero, (D) *a Jakub Plášil, (DD b Joaquín Cobos, (D) c Jiři Sejkora, (D) ${ }^{\mathrm{d}}$ \\ Vicente Timón, (iD a Jiři Čejka, ${ }^{d}$ Ana María Fernández (iD c and Václav Petříček (DD ${ }^{b}$
}

\begin{abstract}
The full crystal structure of the copper-uranyl tetrahydroxide mineral (vandenbrandeite), including the positions of the hydrogen atoms, is established by the first time from X-ray diffraction data taken from a natural crystal sample from the Musonoi Mine, Katanga Province, Democratic Republic of Congo. The structure is verified using first-principles solid-state methods. From the optimized structure, the mechanical and dynamical stability of vandenbrandeite is studied and a rich set of mechanical properties are determined. The Raman spectrum is recorded from the natural sample and determined theoretically. Since both spectra have a high-degree of consistence, all spectral bands are rigorously assigned using a theoretical normal-coordinate analysis. Two bands in the Raman spectra, located at 2327 and $1604 \mathrm{~cm}^{-1}$, are recognized as overtones and a band at $1554 \mathrm{~cm}^{-1}$ is identified as a combination band. The fundamental thermodynamic functions of vandenbrandeite are computed as a function of temperature using phonon calculations. These properties, unknown so far, are key-parameters for the performance-assessment of geological repositories for storage of radioactive nuclear waste and for understanding the paragenetic sequence of minerals arising from the corrosion of uranium deposits. The thermodynamic functions are used here to determine the thermodynamic properties of formation of vandenbrandeite in terms of the elements and the Gibbs free-energies and reaction constants for a series of reactions involving vandenbrandeite and a representative subset of the most important secondary phases of spent nuclear fuel. Finally, from the thermodynamic data of these reactions, the relative stability of vandenbrandeite with respect to these phases as a function of temperature and in the presence of hydrogen peroxide is evaluated. Vandenbrandeite is shown to be highly stable under the simultaneous presence of water and hydrogen peroxide.
\end{abstract}

\section{Introduction}

The use of copper as an exterior canister corrosion barrier for the disposal of radioactive waste was proposed in 1978 in Sweden. ${ }^{1}$ The concept has been adopted by the national

${ }^{a}$ Instituto de Estructura de la Materia (IEM-CSIC), C/Serrano, 113, 28006 Madrid, Spain. E-mail: francisco.colmenero@iem.cfmac.csic.es

${ }^{b}$ Institute of Physics ASCR, v.v.i., Na Slovance 2, 182 21, Praha 8, Czech Republic ${ }^{c}$ Centro de Investigaciones Energéticas, Medioambientales y Tecnológicas (CIEMAT), Avda/ Complutense, 40, 28040 - Madrid, Spain

${ }^{d}$ Mineralogicko-petrologické oddělení, Národni Muzeum, Cirkusová 1740, 19300 Praha 9, Czech Republic

$\dagger$ Electronic supplementary information (ESI) available: (a) Interatomic distances and angles in vandenbrandeite; (b) frontier band functions in vandenbrandeite; (c) pictures of the atomic motions in the Raman active vibrational normal modes of vandenbrandeite; (d) computed fundamental thermodynamic properties of vandenbrandeite as a function of temperature; (e) experimental and theoretical positions of the atoms in the unit cell of vandenbrandeite. CCDC 1952205 and 1946879. For ESI and crystallographic data in CIF or other electronic format see DOI: 10.1039/c9ra09047a research programs of nuclear waste management of many countries including those in Sweden (SKB), ${ }^{1-21}$ Finland (POSIVA), ${ }^{22-27}$ and Canada (NWMO) ${ }^{28-46}$ Copper is also considered as an alternative material in Switzerland (NAGRA), ${ }^{47,48}$ Japan (JNC) ${ }^{49,50}$ and Korea. ${ }^{51}$ The fundamental motivations for the choice of composite canisters with a copper external shell are the observation that copper is essentially inert in an anoxic environment, its large thermodynamic stability at the conditions of a deep geological repository (DGR), and the existence of natural analogues for the long-term corrosion of copper nuclear waste containers. ${ }^{7,8,22,29}$ The disposal models in these countries are similar and comprise an underground repository situated more than four hundred meters below the water table in stable host rock environments which are sealed using a bentonitebased backfill material. Under these conditions, copper provides a very long-lived containment with predicted very long canister lifetimes. ${ }^{9}$ The corrosion of the exterior copper canister barrier as well as a long series of related issues ${ }^{1-57}$ have been studied extensively by the Scandinavian, Finnish and Canadian organizations and many other institutions from the European 
Community. ${ }^{52}$ An entirely new nuclear facility in which the exterior copper canister concept will be put in practice is being developed to handle the permanent disposal of spent nuclear fuel (SNF) at ONKALO (Olkiluoto site, Finland). Finland was the first country to issue a construction license for a DGR, granted in November 2015. The operation license application will be submitted in 2020, the repository being sealed up to $2120 .^{23-27}$

Although the well-established thermodynamic data of copper lead to the expectation that it will corrode to a very limited extent in a closed system ${ }^{2,3,11-14,19-21,28}$ and that this kind of canisters will protect the SNF against corrosion in a stable form during very long times, ${ }^{\mathbf{4 - 6 , 9 , 1 5 , 1 6 , 2 3 , 2 5 , 4 2 - 4 5}}$ the corrosion processes increase upon oxic and humid conditions and high temperatures and pressures. Furthermore, the experiments carried out in the presence of high radiation fields $s^{\mathbf{1 8 , 4 6}}$ show that the dissolution of copper and the rate of formation of oxide layers increase upon radiation significantly, and that aqueous radiation chemistry is not the only process driving the corrosion of copper in these systems. It has been anticipated that, after storage times on the order of thousands of years, the barriers that protect the SNF will be breached and, then, the used fuel will enter in contact with oxygen and water. ${ }^{58}$ Under high radiation fields producing the radiolysis of water at the surface of SNF, the formation of hydrogen peroxide and other oxidant species is expected. ${ }^{59-64}$ An oxidative environment has been postulated $^{65}$ in a layer near the fuel surface (within $<50 \mu \mathrm{m}$ of the fuel surface). Thus, the U(Iv) in the matrix of the SNF, mainly composed of uranium dioxide, could be oxidized to U(vI), and dissolve in water forming uranyl groups. The uranyl groups can precipitate forming secondary phases on the spent fuel surface depending on the local conditions of pressure, temperature, $\mathrm{pH}$ and redox potential and the concentrations of reactive species present. ${ }^{6-69}$ The formation of secondary phases can reduce the release and environmental impact of the fission products and heavier actinides contents in the SNF to the biosphere ${ }^{70}$ because they may be retained in the crystal structures of these phases.

If copper canisters are used, clearly the secondary phases of SNF containing this element will acquire an enormous relevance. In particular, the copper-uranyl tetrahydroxide mineral $\left(\mathrm{Cu}\left(\mathrm{UO}_{2}\right)(\mathrm{OH})_{4}\right)$ vandenbrandeite, studied in this work, is one of the most important uranyl minerals containing copper. Other important uranyl and copper containing minerals are the uranyl silicate cuprosklodowskite, ${ }^{71,72}$ the uranyl carbonates paddlewheelite ${ }^{73}$ and voglite, ${ }^{74}$ the uranyl vanadate sengierite, ${ }^{75}$ the uranyl sulfates johannite, ${ }^{76-78}$ and pseudojohannite, ${ }^{79}$ the uranyl phosphates torbernite, metatorbernite ${ }^{\mathbf{8 0}}$ and ulrichite, ${ }^{\mathbf{8 1 , 8 2}}$ and the uranyl arsenates zeunerite and metazeunerite. ${ }^{80}$ The knowledge of the structures of uranyl minerals ${ }^{83-85}$ is crucial to evaluate the possible incorporation of fission products and transuranic elements into their crystal structures. ${ }^{70,86-88}$ Besides, the study of the crystal structures, spectra and physical and chemical properties of uranyl-containing minerals is fundamental for the study of the corrosion processes occurring in uraninite-bearing ore deposits ${ }^{\mathbf{6 6 9 - 8 9}}$ and for understanding the paragenetic sequence of secondary phases that arises from the corrosion of spent nuclear fuel (SNF) under the final geological disposal conditions..$^{92-98}$
Vandenbrandeite was collected in 1932 by Schoep $^{99}$ in the Kalongwe Copper-Cobalt mine from the Katanga Province in Democratic Republic of Congo (DRC). Its name was coined in honor to Pierre Van den Brande, a Belgian geologist who discovered the Kalongwe deposit. However, this mineral was encountered by the first time a year prior to the finding by Schoep, by Thoreau ${ }^{\mathbf{1 0 0}}$ in the Shinkolobwe uranium mine also from Katanga Province (DRC), and called it uranolepidite. According to the well-known convention that prior names should be preferred, the name uranolepidite should be used, but the name vandenbrandeite has been adopted as the standard name surely due to the most detailed description of the specimen from the Kalongwe mine. Vandenbrandeite is found as a secondary mineral appearing frequently in the oxidation zones of the hydrothermal uranium ore deposits containing copper. Thus, vandenbrandeite mineral is mainly formed from the oxidation and dissolution/precipitation process of uraninite in contact with primary copper minerals. ${ }^{\mathbf{1 0 1 , 1 0 2}}$ Due to his large uranium content, this mineral is extracted from mines for uranium production.

Vandenbrandeite synthetic material was produced by Bignand $^{103}$ in 1955 from mixtures of copper acetate and uranyl acetate at $140{ }^{\circ} \mathrm{C}$ and also by heating schoepite with an excess of copper acetate at $140{ }^{\circ} \mathrm{C}$. The crystal structure of vandenbrandeite was found to be triclinic by Milne and Nuffield ${ }^{\mathbf{1 0 4}}$ in 1951 and was precisely specified by Rosenzweig and Ryan in $1977 .{ }^{105}$ However, the determination of the positions of the hydrogen atoms in the unit-cell of vandenbrandeite has not been possible so far. The infrared spectrum of vandenbrandeite was reported by Povarennykh ${ }^{\mathbf{1 0 6}}$ in 1979 and Čejka and Urbanec $^{107}$ in 1990 but the spectrum was given without interpretation. A detailed investigation on the thermal properties of vandenbrandeite and its infrared spectrum was reported by Čejka in $1994,{ }^{108}$ who assigned the bands in the experimental infrared spectrum empirically.

While the crystal structures of the majority of the uranyl minerals are reasonably well-known, ${ }^{71-84}$ the positions of the hydrogen atoms in their unit cells are unknown in many cases. The solution of this problem is currently being attempted by means of experimental X-ray diffraction techniques ${ }^{72,109-112}$ and first-principles theoretical methods. ${ }^{113-119}$ In the specific case of copper-containing uranyl minerals, the full-crystal structure of cuprosklodowkite was recently determined experimentally. ${ }^{72}$ The full crystal structure of vandenbrandeite, including the positions of the hydrogen atoms within the corresponding unit cell, was first obtained by using the first principles methodology in 2016 (see the ESI of ref. 119). However, it was determined employing small calculation parameters. In the present work, the full crystal structure of vandenbrandeite was determined independently by means of the structure refinement from X-ray diffraction data taken from a natural crystal sample collected from Musonoi Mine (Katanga Province, DRC). The obtained crystal structure was confirmed by means of the first principles solid-state methodology employing accurate calculation parameters, using the previous theoretical structure as initial input.

From the full energy-optimized crystal structure of vandenbrandeite, its elasticity tensor and equation of state ${ }^{\mathbf{1 2 0}}$ were 
computed and used to study the stability of this structure and to determine its mechanical properties using theoretical methods. The values of these properties were predicted since they have not been measured experimentally up to date. The experimental Raman spectrum of vandenbrandeite was recorded from the natural crystal sample from Musonoi Mine (DRC). The corresponding spectrum was also determined using density functional perturbation (DFPT). The computed and experimental spectra were in good agreement and, consequently, all the bands in the Raman spectrum were rigorously assigned to specific vibrational motions using a normal mode analysis of the computed vibrational data.

The fundamental thermodynamic functions of vandenbrandeite (specific heat, entropy, enthalpy and Gibbs free energy) were calculated as a function of temperature using theoretical phonon calculations. ${ }^{\mathbf{1 2 1}}$ The resulting functions were utilized to derive the corresponding enthalpies and Gibbs free energies of formation in terms of the elements as a function of temperature. These thermodynamic properties of formation were then merged with those of other important uranylcontaining materials such as dehydrated schoepite $\left(\mathrm{UO}_{2}(\mathrm{OH})_{2}\right)$, soddyite $\left(\left(\mathrm{UO}_{2}\right)_{2}\left(\mathrm{SiO}_{4}\right) \cdot 2 \mathrm{H}_{2} \mathrm{O}\right)$, rutherfordine $\left(\mathrm{UO}_{2} \mathrm{CO}_{3}\right)$ and gamma uranium trioxide $\left(\gamma-\mathrm{UO}_{3}\right),{ }^{121-125}$ to derive the Gibbs free energies of reaction and the associated reaction constants ${ }^{124,125}$ of the transformation reactions:

$$
\begin{aligned}
\mathrm{UO}_{3}(\mathrm{cr})+\mathrm{CuO}(\mathrm{cr})+2 \mathrm{H}_{2} \mathrm{O}(\mathrm{l}) & \rightarrow \mathrm{Cu}\left(\mathrm{UO}_{2}\right)(\mathrm{OH})_{4}(\mathrm{cr}) \\
\mathrm{UO}_{3} \cdot \mathrm{H}_{2} \mathrm{O}(\mathrm{cr})+\mathrm{CuO}(\mathrm{cr})+\mathrm{H}_{2} \mathrm{O}(\mathrm{l}) & \rightarrow \mathrm{Cu}\left(\mathrm{UO}_{2}\right)(\mathrm{OH})_{4}(\mathrm{cr}) \\
\mathrm{UO}_{2} \mathrm{CO}_{3}(\mathrm{cr})+\mathrm{CuO}(\mathrm{cr})+2 \mathrm{H}_{2} \mathrm{O}(\mathrm{l}) & \rightarrow \mathrm{Cu}\left(\mathrm{UO}_{2}\right)(\mathrm{OH})_{4}(\mathrm{cr}) \\
& +\mathrm{CO}_{2}(\mathrm{~g})
\end{aligned}
$$

$$
\begin{aligned}
1 / 2\left(\mathrm{UO}_{2}\right)_{2}\left(\mathrm{SiO}_{4}\right) \cdot 2 \mathrm{H}_{2} \mathrm{O}(\mathrm{cr}) & +\mathrm{CuO}(\mathrm{cr})+\mathrm{H}_{2} \mathrm{O}(\mathrm{l}) \\
& \rightarrow \mathrm{Cu}\left(\mathrm{UO}_{2}\right)(\mathrm{OH})_{4}(\mathrm{cr})+1 / 2 \mathrm{SiO}_{2}(\mathrm{cr})
\end{aligned}
$$

Similarly, the thermodynamic properties of reaction of the reactions of conversion of vandenbrandeite into schoepite, ${ }^{\mathbf{1 1 4}}$ $\left[\left(\mathrm{UO}_{2}\right)_{8} \mathrm{O}_{2}(\mathrm{OH})_{12}\right] \cdot 12 \mathrm{H}_{2} \mathrm{O}(\mathrm{cr})$, and studtite, ${ }^{121}\left(\mathrm{UO}_{2}\right) \mathrm{O}_{2} \cdot 4 \mathrm{H}_{2} \mathrm{O}$, in the presence of water and hydrogen peroxide and in the presence of high concentrations of hydrogen peroxide, respectively, were obtained by considering the corresponding reactions:

$$
\begin{aligned}
& \mathrm{Cu}\left(\mathrm{UO}_{2}\right)(\mathrm{OH})_{4}(\mathrm{cr})+1 / 8 \mathrm{H}_{2} \mathrm{O}(\mathrm{l})+1 / 8 \mathrm{H}_{2} \mathrm{O}_{2}(\mathrm{l}) \\
& \rightarrow 1 / 8\left[\left(\mathrm{UO}_{2}\right)_{8} \mathrm{O}_{2}(\mathrm{OH})_{12}\right] \cdot 12 \mathrm{H}_{2} \mathrm{O}(\mathrm{cr})+\mathrm{CuO}(\mathrm{cr})+1 / 16 \mathrm{O}_{2}(\mathrm{~g})(\mathrm{E}) \\
& \mathrm{Cu}\left(\mathrm{UO}_{2}\right)(\mathrm{OH})_{4}(\mathrm{cr})+2 \mathrm{H}_{2} \mathrm{O}_{2}(\mathrm{l}) \rightarrow\left(\mathrm{UO}_{2}\right) \mathrm{O}_{2} \cdot 4 \mathrm{H}_{2} \mathrm{O}(\mathrm{cr}) \\
&+\mathrm{CuO}(\mathrm{cr})+1 / 2 \mathrm{O}_{2}(\mathrm{~g})
\end{aligned}
$$

The temperature dependent thermodynamic properties are key parameters for the performance assessment of radioactive waste repositories because the stability of the secondary phases of the spent nuclear fuel under final geological disposal conditions is highly dependent of the temperature. ${ }^{\mathbf{1 2 4 , 1 2 5}}$ The computed thermodynamic parameters together with those derived in previous works ${ }^{\mathbf{1 1 4 , 1 1 5 , 1 2 1 - 1 2 5}}$ permitted to determine the thermodynamic stability of vandenbrandeite with respect to a selected set of the most relevant secondary phases of SNF under final geological disposal conditions.

One of the most important motivations of this work is to contribute to the development of nuclear $\operatorname{Raman}^{113,117-120}$ and thermodynamic databases. ${ }^{\mathbf{1 4 4 1 1 5 , 1 2 1 - 1 2 5 , 1 2 5 - 1 2 9}}$ Raman spectroscopy is one of the main techniques used to identify uraniumcontaining materials because it does not need a special preparation of the samples, a very small amount of sample is required and it is non-destructive. Thus, this spectroscopic technique minimizes the difficulties in the handling of these materials associated to its radiotoxicity and the costs of the analyses because the samples may be reutilized. Furthermore, the use of the first principles methodology allows for a rigorous assignment of the Raman bands, customarily performed using rough empirical arguments frequently leading to incomplete and even incorrect assignments. The availability of accurate thermodynamic information is indispensable in nuclear sciences because it permits to model the dynamical behavior nuclear materials under diverse geochemical conditions. An accurate thermodynamic database is a prerequisite in calculations supporting the safety performance assessment of radioactive waste disposal systems. ${ }^{128,129}$ The stabilities and dissolution rates of uranyl minerals are functions of their composition, temperature, and local conditions (mainly $\mathrm{pH}$ and redox potential), and their prediction requires the knowledge of the Gibbs free energy, enthalpy, and entropy thermodynamic functions of formation for each phase of interest and their variation with temperature. While the amount of thermodynamic data available at normal conditions is quite large, reliable temperature dependent thermodynamic information is completely lacking for most of the uranyl containing materials. ${ }^{\mathbf{1 2 6 , 1 2 7}}$ For the case of vandenbrandeite, there are not thermodynamic data even at room temperature. The development of a more complete nuclear thermodynamic database using the first principles methodology combined with experimental techniques should permit to carry out realistic thermodynamic computations involving a significant number of these materials, providing a profound understanding of uranium mineral paragenesis and of the corrosion processes in uranium deposits and SNF repositories.

This paper is structured as follows. In Section 2, the experimental and first principles solid state methods employed in this work are described. The experimental full crystal structure of vandenbrandeite derived from X-ray diffraction data is also reported. Section 3 contains the main results of this work and the discussion of these results. The results concerning the crystal structure, the hydrogen bonding, the computed X-ray diffraction pattern, and the mechanical, spectroscopic and thermodynamic properties of vandenbrandeite are considered in six separate subsections. Finally, the conclusions of this work are presented in Section 4.

\section{Materials and methods}

\subsection{Experimental}

2.1.1. Single crystal X-ray diffraction. Crystal structure refinement. A natural sample of vandenbrandeite from Musonoi Mine, Katanga Province (DRC), composed by dark 
green prismatic crystals up to $1 \mathrm{~mm}$ in length was analyzed by means of single-crystal X-ray diffraction. A long-prismatic fragment $(0.065 \times 0.052 \times 0.025 \mathrm{~mm})$ of a vandenbrandeite crystal was selected for data collection at room temperature with a Rigaku SuperNova single-crystal diffractometer $\left(\mathrm{MoK}_{\alpha}\right.$ radiation from a micro-focus X-ray tube collimated and monochromatized by mirror-optics and detected by an Atlas S2 CCD detector). It was found that vandenbrandeite was triclinic, space group $P \overline{1}$, with $a=5.4597(3) \AA, b=6.1034(3) \AA$, $c=7.8652(4) \AA, \alpha=78.057(5)^{\circ}, \beta=89.804(4)^{\circ}, \gamma=88.612(4)^{\circ}$ $\left(V=256.341(2) \AA^{3}(Z=2)\right)$. These unit-cell parameters are in good agreement with the values reported by Rosenzweig and Ryan. ${ }^{105}$ Integration of the diffraction data, including corrections for background, polarization and Lorentz effects and absorption correction was carried out with the CrysAlis RED program. ${ }^{130}$ The crystal structure of vandenbrandeite was solved by the charge-flipping algorithm using the SHELXT program. ${ }^{131}$ The structure was then refined using the software Jana2006 with the full-matrix least-squares refinement based on $F^{2}{ }^{132}$ The structure solution included the locations of all atoms except hydrogens. The positions of hydrogen atoms were later established from the differenceFourier maps. The $\mathrm{H}$ atoms were refined using a mix of soft constraints on $\mathrm{O}-\mathrm{H}$ distances, 0.95(4) $\AA$, and with the atomic displacement parameter, $U_{\text {eq }}$, of each $\mathrm{H}$ set to 1.2 times that of the donor $\mathrm{O}$ atom.

2.1.2. Raman spectroscopy. The Raman spectrum of vandenbrandeite was collected from the natural crystal sample from Musonoi Mine (DRC). The Raman spectra were obtained in the range from 4000 to $40 \mathrm{~cm}^{-1}$ using a DXR dispersive Raman Spectrometer (Thermo Scientific) mounted on a confocal Olympus microscope. The Raman signal was excited by an unpolarized red $633 \mathrm{~nm} \mathrm{He-Ne} \mathrm{gas} \mathrm{laser} \mathrm{and}$ detected by a CCD detector. The experimental parameters were: $100 \times$ objective, $10 \mathrm{~s}$ exposure time, 300 exposures, $50 \mu \mathrm{m}$ slit spectrograph aperture and $6 \mathrm{~mW}$ laser power level. The spectra were repeatedly acquired from different grains in order to obtain a representative spectrum with the best signal-tonoise ratio. The eventual thermal damage of the measured point was excluded by visual inspection of excited surface after measurement, by observation of possible decay of spectral features in the start of excitation and checking for thermal downshift of Raman lines. The instrument was set up by a software-controlled calibration procedure using multiple neon emission lines (wavelength calibration), multiple polystyrene Raman bands (laser frequency calibration) and standardized white-light sources (intensity calibration). Spectral manipulations were performed using the Omnic 9 software (Thermo Scientific).

\subsection{Theoretical solid-state methods}

2.2.1. Crystal structure. The vandenbrandeite crystal structure was obtained by using the Cambridge Serial Total Energy Program (CASTEP), ${ }^{133}$ a program of the Materials Studio program suite. ${ }^{134}$ All the computations were performed with the Perdew-Burke-Ernzerhof (PBE) energy-density functional ${ }^{135}$ complemented with Grimme's empirical dispersion correction $^{136}$ (DFT-D2 approach). Periodic Density Functional Theory based on plane wave basis sets and pseudopotentials to describe the internal atomic electrons ${ }^{137}$ was utilized. The specific pseudopotentials employed were standard normconserving pseudopotentials ${ }^{138}$ from CASTEP package for the $\mathrm{Cu}, \mathrm{O}$ and $\mathrm{H}$ atoms in the unit cell of vandenbrandeite. For the $\mathrm{U}$ atom, a relativistic norm-conserving pseudopotential generated from first principles ${ }^{119,139}$ was used. This pseudopotential has been validated widely for the research of the crystal structures, vibrational spectra and properties of uranium containing materials. ${ }^{113-125,139-144}$

The unit-cell parameters of vandenbrandeite and the associated atomic positions were fully optimized by means of the Broyden-Fletcher-Goldfarb-Shanno (BFGS) technique. ${ }^{145}$ A large plane wave kinetic energy cut-off parameter of $\varepsilon=1000 \mathrm{eV}$ and a dense $k$-mesh ${ }^{146}$ of $3 \times 5 \times 4$ (30 $k$-points) were employed. These calculation parameters were selected to produce a well converged crystal structure, energy and properties. The X-ray powder diffraction patterns of vandenbrandeite were obtained ${ }^{147}$ from the experimental and computed crystal structures using the software REFLEX included in Materials Studio program suite. ${ }^{134}$

The influence of the Hubbard correction, ${ }^{148}$ allowing for a correct description of the strong Coulomb repulsion between electrons in f orbitals, was also evaluated. The introduction of this correction, improving significantly the description of uranium containing systems in which uranium exists with IV oxidation state, ${ }^{149-154}$ seems not to be needed for vandenbrandeite as shown in Section 3. In fact, for a numerous set of materials in which uranium exists with VI oxidation state, the standard DFT description provides a reliable description of their structures and properties. ${ }^{113-125,139-144,155-162}$

2.2.2. Elastic tensor and equation of state. The technique of finite deformations ${ }^{163}$ was employed to determine the matrix elements of the stiffness tensor ${ }^{164}$ needed to compute the elastic properties of vandenbrandeite and to evaluate the mechanical stability of its crystal structure. This method, which appears to be more efficient for this purpose than density functional perturbation theory and the energy based methods, ${ }^{163}$ has been effectively applied for the computation of the elastic response of many solid materials. ${ }^{113,115-118,120,122,141,142,144,165-169}$ The derivatives of the bulk modulus with respect to pressure were determined by fitting the lattice volumes and associated pressures to a $4^{\text {th }}$ order Birch-Murnahan equation of state. ${ }^{170}$ The unit cell volumes in the neighborhood of the optimized structure were obtained by optimizing the vandenbrandeite crystal structure under sixteen different external pressures with values in the range -1.0 to $9.0 \mathrm{GPa}$. The fit of the pressure-volume data to the selected equation of state was performed employing Angel's EOSFIT 5.2 code. $^{171,172}$ The optimizations under pressure were also performed using the BFGS method. ElAM computer program ${ }^{173}$ was employed to obtain the $3 \mathrm{D}$ representations of the mechanical properties of vandenbrandeite as a function of the direction of the applied strain.

2.2.3. Raman spectrum. The theoretical determination of the Raman spectra of vandenbrandeite was performed using 
density functional perturbation theory. ${ }^{\mathbf{1 7 4 - 1 7 6}}$ The computed values of the Raman shifts and the corresponding band intensities correspond to the harmonic approximation of the interatomic force field and no scaling procedures were applied. These scaling procedures are frequently used to improve the computed Raman shifts by correcting them empirically for the anharmonicity and remaining approximations used in the specific theoretical treatment used. ${ }^{177}$ However, the unscaled Raman shifts obtained using the DFPT method in previous works ${ }^{113,117-120,123,139-143}$ have provided consistently accurate descriptions of the vibrational spectra of uranyl-containing materials. Therefore, we considered advisable to employ the DFTP method without applying any kind of scaling procedure.

\subsubsection{Thermodynamic properties}

2.2.4.1. Fundamental thermodynamic properties. The fundamental thermodynamic functions of vandenbrandeite were obtained by performing phonon calculations at the optimized structure. The phonon spectra at all the points of the Brillouin zone were calculated by means of the density functional perturbation theory (DFPT) method as second order derivatives of the total energy. ${ }^{\mathbf{1 7 4}}$ The phonon dispersion curves and density of states were calculated from the computed phonon spectra and, from them, the fundamental thermodynamic functions (Gibbs free energies, enthalpies, entropies, and specific heats) were obtained in the quasi-harmonic approximation. ${ }^{\mathbf{1 7 8 , 1 7 9}}$ The thermodynamic properties of formation and reaction were then evaluated in terms of the calculated fundamental thermodynamic properties using the methods described in the next subsections. ${ }^{\mathbf{1 2 1 , 1 2 4 , 1 2 5}}$

2.2.4.2. Thermodynamic properties of formation. The calculated enthalpy and entropy functions, $\left(H_{T}-H_{298}\right)^{\text {calc }}$ and $S_{T}^{\text {calc }}$, were employed to obtain the enthalpy and Gibbs freeenergy of formation in terms of the elements by means of the equations: ${ }^{\mathbf{1 2 1 , 1 8 0}}$

$$
\begin{gathered}
\Delta_{\mathrm{f}} H(T)=\Delta_{\mathrm{f}} H^{0}+\left(H_{T}-H_{298}\right)^{\mathrm{calc}}+\sum_{i}^{\text {elements }} n_{i}\left(H_{T}-H_{298}\right)_{i}^{\text {exp }} \\
\Delta_{\mathrm{f}} G(T)=\Delta_{\mathrm{f}} H(T)-T\left\{S_{T}^{\text {calc }}-\sum_{i}^{\text {elements }} n_{i}\left(S_{T}\right)_{i}^{\exp }\right\}
\end{gathered}
$$

In these relations, $\Delta_{\mathrm{f}} H^{0}$ is the enthalpy of formation at the standard state of the material being investigated (temperature of $295.15 \mathrm{~K}$ and pressure of $1 \mathrm{bar})$, and $\left(H_{T}-H_{298}\right)_{i}^{\exp }$ and $\left(S_{T}\right)_{i}^{\exp }$ are the enthalpy and entropy functions of the elements forming part of this material with stoichiometric coefficients $n_{i}$, respectively. The precise value of $\Delta_{\mathrm{f}} H^{0}$ for vandenbrandeite employed in this work will be given below. The thermodynamic functions for copper, oxygen and hydrogen were taken from JANAF (Joint Army-Navy-Air Force) thermochemical tables ${ }^{\mathbf{1 8 0}}$ and those for uranium from the book by Barin. ${ }^{181}$ The reaction constants of the formation reactions were calculated from the corresponding Gibbs free energies of formation employing the relationship: ${ }^{\mathbf{1 8 0}}$

$$
\Delta G(T)=-R T \ln K
$$

2.2.4.3. Thermodynamic properties of reaction. The enthalpies and Gibbs free energies of reaction at the different temperatures were calculated from the computed Gibbs free energy and entropy of formation functions, $\Delta_{\mathrm{f}} G(T)^{\text {calc }}$ and $\Delta_{\mathrm{f}} S(T)^{\text {calc }}$, by means of the expressions: ${ }^{\mathbf{1 2 4 , 1 8 0}}$

$$
\begin{gathered}
\Delta_{\mathrm{r}} G(T)=\sum_{i}^{\text {products }} n_{i} \Delta_{\mathrm{f}} G^{i}(T)-\sum_{j}^{\text {reactants }} n_{j} \Delta_{\mathrm{f}} G^{j}(T) \\
\Delta_{\mathrm{r}} H(T)=\Delta_{\mathrm{r}} G(T)+T \Delta_{\mathrm{r}} S(T)
\end{gathered}
$$

where,

$$
\Delta_{\mathrm{r}} S(T)=\sum_{i}^{\text {products }} n_{i} \Delta_{\mathrm{f}} S^{i}(T)-\sum_{j}^{\text {reactants }} n_{j} \Delta_{\mathrm{f}} S^{j}(T)
$$

In these equations, $\Delta_{\mathrm{f}} G^{i}(T)$ and $\Delta_{\mathrm{f}} S^{i}(T)$ denote the Gibbs free energy and entropy of formation at temperature $T$ of the compound $i$ entering in the reaction with stoichiometric coefficient $n_{i}$. The thermodynamic functions for $\mathrm{CuO}(\mathrm{cr}), \mathrm{SiO}_{2}(\mathrm{cr})$, $\mathrm{H}_{2} \mathrm{O}(\mathrm{l}), \mathrm{CO}_{2}(\mathrm{~g})$, and $\mathrm{O}_{2}(\mathrm{~g})$ were taken from JANAF thermochemical tables ${ }^{\mathbf{1 8 0}}$ and those of $\mathrm{H}_{2} \mathrm{O}_{2}(\mathrm{l})$ from Barin. ${ }^{\mathbf{1 8 1}}$ The reaction constants were calculated from the Gibbs free energies of reaction by using the eqn (3).

\section{Results and discussion}

\subsection{Crystal structure}

Uranium atom in vandenbrandeite displays pentagonal bipyramidal coordination. Fixing the cutoff for the $\mathrm{Cu}-\mathrm{O}$ bondlength to $3.2 \AA$, the copper atom displays distorted octahedral coordination. Although two of the oxygen atoms in the coordination sphere of copper atom have $\mathrm{Cu}-\mathrm{O}$ distances which are much larger than the remaining four oxygen atoms, the analysis of the computed electron density of vandenbrandeite using Bader's theory ${ }^{\mathbf{1 8 2}}$ for the quantum mechanical description of the chemical bond confirmed that they must be included in the coordination structure of copper atom. In vandenbrandeite, the uranium and cooper coordination polyhedra form dimers by sharing an equatorial edge with another polyhedra of the same kind. The main building blocks in the crystal structure of vandenbrandeite are shown in Fig. 1A. The copper dimers share two faces (one from each monomer) with uranium dimers to form uranyl cuprate layers as shown in the Fig. 1B. Finally, the uranyl cuprate layers are linked by sharing the uranium and copper polyhedra apical vertices as shown in the Fig. 1C.

The unit cell of vandenbrandeite is triclinic, space group $P \overline{1}$ (no. 2). The computed unit-cell parameters, volume and density are given in Table 1 where they are compared with the corresponding experimental data. The differences between the calculated and experimental volumes are only about $0.3 \%$ with respect to the present crystal data and $0.8 \%$ with respect to those from Rosenzweig and Ryan. ${ }^{\mathbf{1 0 5}}$ The dispersion corrections improved significantly the computed crystal structure of vandenbrandeite since, as it can be seen in the first line of Table 1, 
$\boldsymbol{A}$
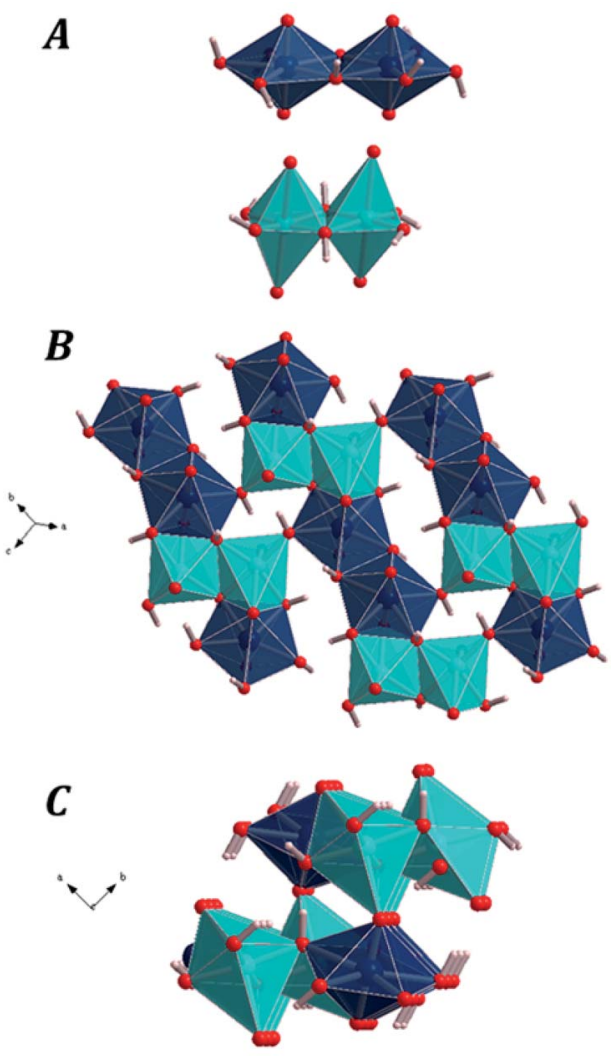

Fig. 1 The computed crystal structure of vandenbrandeite: (A) The dimers of the uranyl and copper polyhedra; (B) An uranyl cuprate layer: (C) two connected successive uranyl cuprate layers. Color code: U dark blue; $\mathrm{Cu}$ - clear blue; $\mathrm{O}$ - red; $\mathrm{H}$ - white.

the computed unit-cell volume obtained using the uncorrected PBE energy-density functional overestimates the experimental volume significantly $(2.8 \%)$.

The Hubbard correction (which was applied with the parameter ${ }^{152} U_{\text {eff }}=4.0 \mathrm{eV}$ ) does not introduce significant changes to the computed crystal structure as shown in the third row of Table 1. Since the Hubbard correction does not improve the description of vandenbrandeite, it was not used to obtain the properties and spectra of this mineral. The reason of the small impact of this correction is clear from Fig. S.1 of the ESI $\dagger$ where the frontier band functions (the highest occupied and lowest unoccupied one-electron wavefunctions), are displayed. Standard DFT predicts correctly that vandenbrandeite is an insulator with a band gap of $0.72 \mathrm{eV}$. As can be seen, the highest occupied band function is predominantly composed of contributions localized in $\mathrm{d}$ orbitals of copper atoms and $\mathrm{p}$ orbitals of oxygen atoms. The lowest unoccupied wavefunction represents mainly a combination of contributions localized in $f$ orbitals of uranium atoms. Since the forbitals in uranium are unoccupied, the Hubbard correction describing strong correlation between electrons occupying this type of orbitals is not required.

An illustrative set of interatomic distances and angles in vandenbrandeite are given in Tables S.1 and S.2 of the ESI, $\dagger$ respectively. As can be seen, the theoretical and experimental values are in very good agreement. The unit cell of vandenbrandeite contains only one symmetrically independent $\mathrm{U}$ atom and one symmetrically independent $\mathrm{Cu}$ atom in its unit cell. The uranyl oxygen atoms located in the apical positions of the uranium pentagonal bipyramids have uraniumoxygen distances of $1.786(3)$ and 1.801(3) $\AA$, which may be compared with the computed values of 1.806 and $1.819 \AA$, respectively. The average $\mathrm{U}-\mathrm{O}$ distance for the five equatorial $\mathrm{O}$ atoms is $2.38 \AA$, which hopefully coincides with the theoretical value. Similarly, the experimental and theoretical average $\mathrm{Cu}-\mathrm{O}$ distances, 2.25 and $2.30 \AA$ agree satisfactorily within $0.05 \AA$.

The experimental and computed full crystal structures of vandenbrandeite are reported as ESI $\dagger$ in two files of CIF (Crystallographic Information File) type. It should be noticed that in the theoretical structure CIF file the coordinate system axes are permuted with respect to those of the experimental structure in the form $a \rightarrow b^{\prime} ; b \rightarrow-c^{\prime} ; c \rightarrow a^{\prime}$. In this coordinate system, the slight triclinic distortion in vandenbrandeite with respect to a monoclinic system is more clearly shown because in this reference system the computed unit-cell parameters become $a=7.8348 \AA, b=5.4450 \AA, c=6.1331 \AA, \alpha=89.4481^{\circ}, \beta=$ $100.8179^{\circ}$, and $\gamma=90.2831^{\circ}$.

\subsection{Hydrogen bonding}

There are four inequivalent hydrogen bonds in vanden-

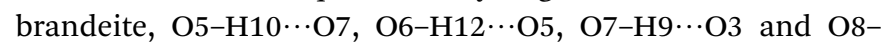
H11 $\cdots$ O 4 . As shown in Tables S.1 and S.2 of the ESI, $\dagger$ all of them are short and quite nearly linear. Except for the first hydrogen bond $\mathrm{O} 5-\mathrm{H} 10 \cdots \mathrm{O} 7$, which is fully contained with a given uranylcuprate layer, the remaining hydrogen bonds link two different layers as shown in Fig. 2.

Table 1 Unit-cell parameters, volume and density of vandenbrandeite. The experimental and theoretical values correspond to room temperature and $0 \mathrm{~K}$, respectively

\begin{tabular}{lllllllll}
\hline Parameter & $a(\AA)$ & $b(\AA)$ & $c(\AA)$ & $\alpha(\mathrm{deg})$ & $\beta(\mathrm{deg})$ & $\gamma(\mathrm{deg})$ & ${\text { Vol. }\left(\AA^{3}\right)}^{\left.\text {Dens. }(\mathrm{g} \mathrm{cm})^{-3}\right)}$ \\
\hline PBE & 5.4748 & 6.1774 & 7.9337 & 79.2226 & 90.1392 & 89.6109 & 263.5805 \\
DFT-D2 & 5.4450 & 6.1331 & 7.8348 & 79.1821 & 90.2831 & 89.4481 & 256.9770 & 5.060 \\
DFT-D2+U & 5.4440 & 6.1311 & 7.8343 & 79.1664 & 90.2913 & 89.4393 & 256.8154 \\
Exp [this work] & $5.4597(3)$ & $6.1034(3)$ & $7.8652(4)$ & $78.057(5)$ & $89.804(4)$ & $88.612(4)$ & $256.341(2)$ & 5.193 \\
Exp. $^{105}$ & 5.449 & 6.089 & 7.855 & 78.10 & 89.20 & 88.56 & 254.929
\end{tabular}




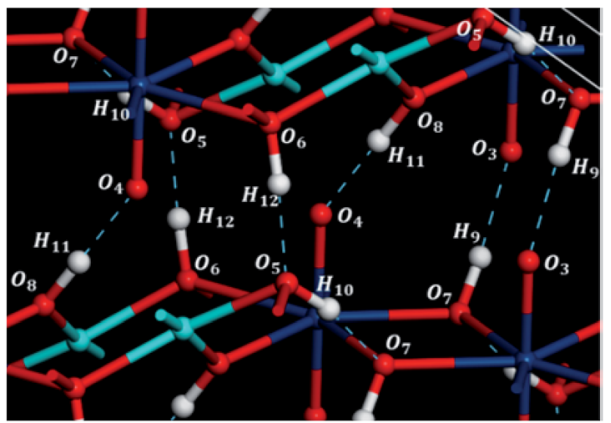

Fig. 2 Hydrogen bond structure in vandenbrandeite. Color code: $U$ dark blue; $\mathrm{Cu}$ - clear blue; $\mathrm{O}$ - red; $\mathrm{H}$ - white.

\subsection{X-ray powder diffraction patterns}

The software REFLEX included in Materials Studio program suite $^{\mathbf{1 3 4}}$ was utilized in order to obtain the X-ray powder diffraction patterns of vandenbrandeite from the theoretical and experimental crystal structures using $\mathrm{CuK}_{\alpha}$ radiation $(\lambda=$ $1.540598 \AA$ ). These patterns are compared in Fig. 3 in which a true experimental X-ray powder diffraction pattern of vandenbrandeite ${ }^{\mathbf{1 8 3 , 1 8 4}}$ is also included. The last pattern is from a natural sample from Shinkolobwe Mine, Shaba, Democratic Republic of Congo, taken from Record R080114 of RRUFF database. ${ }^{\mathbf{1 8 3 , 1 8 4}}$ The agreement of the computed and experimental diffractograms is excellent. A more detailed comparison is provided in Table 2, in which the calculated and experimental positions and intensities of the main reflections are given. As can be observed, the X-ray powder pattern of vandenbrandeite is complex and contains a large number of reflections with

Table 2 Main reflections in the X-ray powder pattern of vandenbrandeite: (a) X-ray powder pattern computed from the computed crystal structure; (b) experimental diffractogram (from Record R080114 of RRUFF database $\left.{ }^{184}\right)$. The last column contains the differences between the computed and experimental positions of all reflections

(b)

(a) Calculated

\begin{tabular}{rrrlrrrr}
\cline { 1 - 1 } $2 \theta\left(^{\circ}\right)$ & $d(\AA)$ & $I(\%)$ & {$[h k l]$} & & $2 \theta\left(^{\circ}\right)$ & $I(\%)$ & $\Delta(2 \theta)$ \\
\hline 19.99 & 4.44 & 100.00 & {$[101]$} & 20.05 & 100.00 & -0.06 \\
16.89 & 5.25 & 85.64 & {$[011]$} & 16.86 & 93.23 & 0.03 \\
26.21 & 3.40 & 40.50 & {$[-1-11]$} & 26.18 & 35.78 & 0.03 \\
21.89 & 4.06 & 32.24 & {$[-110]$} & 22.39 & 29.65 & -0.50 \\
29.78 & 3.00 & 35.05 & {$[0-12]$} & 30.15 & 28.23 & -0.37 \\
19.93 & 4.45 & 27.14 & {$[-101]$} & 20.08 & 26.84 & -0.15 \\
29.85 & 2.99 & 28.71 & {$[-112]$} & 30.03 & 26.19 & -0.18 \\
23.10 & 3.85 & 26.14 & {$[002]$} & 23.17 & 22.04 & -0.07 \\
16.27 & 5.44 & 18.58 & {$[100]$} & 16.31 & 20.04 & -0.04 \\
14.69 & 6.02 & 17.31 & {$[010]$} & & 14.87 & 19.46 & -0.18 \\
29.73 & 3.00 & 18.71 & {$[021]$} & 29.84 & 18.71 & -0.11 \\
33.91 & 2.64 & 25.76 & {$[0-21]$} & 34.44 & 18.64 & -0.53 \\
33.92 & 2.64 & 13.95 & {$[-121]$} & 34.52 & 18.11 & -0.60 \\
28.34 & 3.15 & 17.34 & {$[-102]$} & 28.41 & 13.35 & -0.07 \\
35.34 & 2.54 & 15.47 & {$[013]$} & 35.19 & 12.78 & 0.15 \\
23.65 & 3.76 & 13.58 & {$[111]$} & 23.31 & 12.65 & 0.34 \\
30.08 & 2.97 & 15.76 & {$[112]$} & 29.73 & 11.47 & 0.35 \\
34.12 & 2.63 & 13.89 & {$[120]$} & 33.96 & 10.82 & 0.16 \\
36.30 & 2.47 & 12.61 & {$[210]$} & 35.99 & 8.78 & 0.31 \\
48.65 & 1.87 & 10.50 & {$[-203]$} & 48.78 & 8.56 & -0.13 \\
50.20 & 1.82 & 9.96 & {$[-104]$} & 50.35 & 8.29 & -0.15 \\
38.21 & 2.35 & 12.22 & {$[122]$} & 37.71 & 7.68 & 0.50 \\
44.91 & 2.02 & 8.08 & {$[-123]$} & 45.10 & 7.57 & -0.19 \\
44.11 & 2.05 & 11.84 & {$[-1-13]$} & 44.33 & 7.47 & -0.22
\end{tabular}

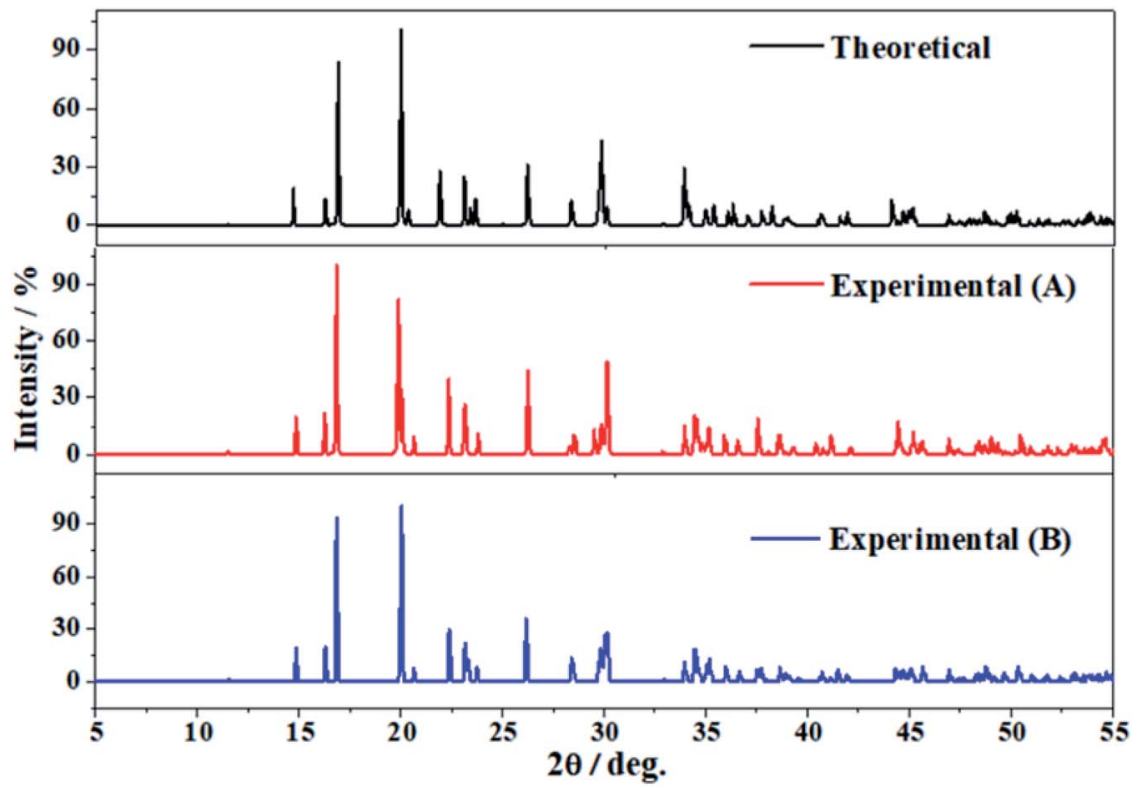

Fig. $3 \mathrm{X}$-ray diffraction powder patterns of vandenbrandeite using $\mathrm{CuK}_{\alpha}$ radiation $(\lambda=1.540598 \AA)$. The upper pattern has been determined from the calculated geometry. The mid pattern was obtained from the experimental geometry reported in this work. Finally the lower diffractogram is an experimental X-ray diffraction pattern from a natural sample from Shinkolobwe Mine, Shaba, Democratic Republic of Congo, taken from Record R080114 of RRUFF database. ${ }^{183,184}$ 
intensities larger than $10 \%$. The reflection having the largest difference in the calculated position with respect to experiment is $[-121]\left(2 \theta \sim 34.5^{\circ}\right)$, the difference being only about 0.6 degrees.

\subsection{Mechanical properties and stability}

3.4.1. Stiffness tensor and stability. Because vandenbrandeite unit-cell possess triclinic space symmetry, the matrix elements of the matrix representation of the stiffness tensor are not related by symmetry and there are twenty one nonvanishing independent tensor elements, $C_{i j}(i \leq j) .{ }^{156,164}$ The calculated values of these matrix elements are given in Table S.3 of the ESI. $\uparrow$ The indices of the matrix elements of the stiffness tensor are expressed using the standard Voigt notation in which a pair of Cartesian indices are contracted into a single integer (1 $\leq i \leq 6: x x \rightarrow 1, y y \rightarrow 2, z z \rightarrow 3, y z \rightarrow 4, x z \rightarrow 5, x y \rightarrow 6)$.

The generic necessary and sufficient Born condition ${ }^{\mathbf{1 8 5 , 1 8 6}}$ for mechanical stability of a crystal structure is that the stiffness matrix $C$ should be positive definite, i.e. all its eigenvalues should be positive. A numerical diagonalization of the $C$ matrix of vandenbrandeite was carried out. The crystal structure of vandenbrandeite is mechanically stable because all the eigenvalues were found to be positive. Besides, the fulfillment of the dynamical stability condition of the structure was analyzed from phonon calculations. A crystal structure is dynamically stable, if and only if, all its phonon modes have positive frequencies for all wave vectors. ${ }^{186}$ The calculated phonon density of states is shown in Fig. S.2 of the ESI. $\dagger$ As shown clearly in this figure, there are not negative energy phonons for vandenbrandeite. Consequently, the crystal structure of vandenbrandeite is mechanically and dynamically stable.

3.4.2. Mechanical properties. The Voigt, ${ }^{187}$ Reuss, ${ }^{188}$ and Hill $^{189}$ approaches were used to calculate the mechanical properties of polycrystalline aggregates of vandenbrandeite. As it has been encountered in many preceding works, ${ }^{113,115-117,123,141,165,166,168,169}$ the Reuss approach provided the best agreement between the calculated bulk modulus with the value of the single crystal bulk modulus obtained from the Birch-Murnahan equation of state (see next Section). The results obtained for the calculated elastic properties in the Reuss approximation are reported in Table 3. Since the calculated ductility index, $D=1.67$, is smaller than 1.75 , vandenbrandeite is a brittle material. ${ }^{\mathbf{9 0 0}, \mathbf{1 9 1}}$ The calculated Vickers hardness is $H=3.71$ and, hence, vandenbrandeite is a material of intermediate hardness. ${ }^{192}$ The computed universal anisotropy index, ${ }^{193} A^{\mathrm{U}}=0.84$, is quite small and, therefore, vandenbrandeite is quite isotropic mechanically. This feature, indicated by the anisotropy index, is also clearly shown by the featureless dependence of the compressibility (the inverse of bulk modulus), Young and shear moduli and Poisson's ratio as a function of the direction of the applied strain, which is displayed in Fig. 4.

3.4.3. Equation of state and bulk modulus pressure derivatives. The unit-cell volumes of vandenbrandeite under the effect of sixteen hydrostatic external pressures were determined
Table 3 Computed mechanical properties of vandenbrandeite in the Reuss approximation. The values of the bulk, shear and Young moduli $(B, G$ and $E$ ) are given in GPa. The computed bulk modulus and their pressure derivatives derived from the EOS are also given

\begin{tabular}{llr}
\hline Property & & Value \\
\hline$B$ & Bulk modulus & 36.97 \\
$G$ & Shear modulus & 22.12 \\
$E$ & Young modulus & 55.33 \\
$\nu$ & Poisson ratio & 0.25 \\
$D$ & Ductility index & 1.67 \\
$H$ & Hardness index & 3.71 \\
$A^{\mathrm{U}}$ & Universal anisotropy index & 0.84 \\
& & \\
EOS & & \\
$B$ & Bulk modulus & $39.48 \pm 0.74$ \\
$B^{\prime}$ & Bulk modulus first derivative & $4.55 \pm 0.75$ \\
$B^{\prime \prime}$ & Bulk modulus second & $0.27 \pm 0.28$ \\
& derivative &
\end{tabular}

by optimizing its crystal structure using the BFGS method. The results are shown in Fig. S.3 of the ESI. $\dagger$ Then, EOSFIT 5.2 program $^{171,172}$ was employed to fit the pressure-volume data to a $4^{\text {th }}$ Birch-Murnaghan $^{170}$ equation of state (EOS),

$$
\begin{aligned}
P & =3 B f_{\mathrm{E}}\left(1+2 f_{\mathrm{E}}\right)^{\frac{5}{2}}\left[1+\frac{3}{2}\left(B^{\prime}-4\right) f_{\mathrm{E}}\right. \\
& \left.+\frac{3}{2}\left\{B B^{\prime \prime}+\left(B^{\prime}-4\right)\left(B^{\prime}-3\right) \frac{35}{9}\right\} f_{\mathrm{E}}{ }^{2}\right]
\end{aligned}
$$

where:

$$
f_{\mathrm{E}}=\frac{1}{2}\left[\left(\frac{V_{0}}{V}\right)^{\frac{2}{3}}-1\right]
$$

The fitted EOS parameters are the bulk modulus and its first two derivatives with respect to pressure. The values found are
A

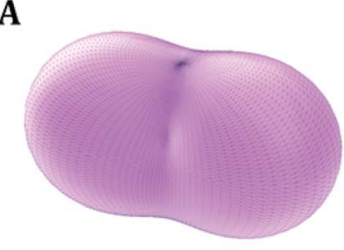

C

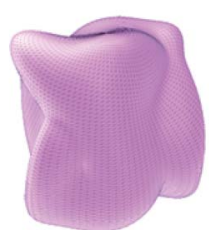

B

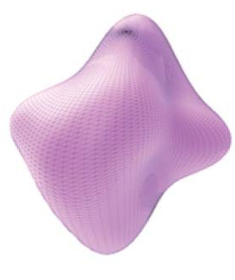

D

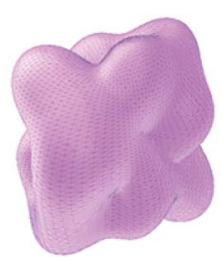

Fig. 4 Elastic properties of vandenbrandeite mineral as a function of the orientation of the applied strain: (A) compressibility; (B) Young modulus; (C) shear modulus; (D) Poisson ratio. The maximum values of the compressibility, Young modulus, shear modulus and Poisson's ratio are $15.46 \mathrm{TPa}^{-1}, 85.21 \mathrm{GPa}, 35.22 \mathrm{GPa}$ and 0.56 , respectively. 
given in Table 3 . The calculated bulk modulus, $B=39.48 \pm$ $0.74 \mathrm{GPa}$, is in excellent agreement with the value derived from the computed elastic constants, $B=36.97 \pm 0.27 \mathrm{GPa}$.

\subsection{Raman spectroscopic characterization}

The Raman spectrum of vandenbrandeite was recorded from a natural crystal sample from Musonoi Mine, Katanga Province (DRC) and determined using the first principles methodology. The experimental and theoretical spectra are compared in Fig. 5. The theoretical calculations reproduced satisfactorily the observed Raman spectrum. The band wavenumbers of both spectra along with the corresponding calculated intensities and assignments are given in Table 4. A series of pictures of the atomic motions in some Raman active vibrational modes are provided in Fig. S.4 of the ESI. $\dagger$ The Raman spectrum is analyzed in five different wavenumber regions: (i) OH stretching vibrations region from 3600 to $2700 \mathrm{~cm}^{-1}$ (Fig. 5A); (ii) the region from 2700 to $1300 \mathrm{~cm}^{-1}$ (Fig. 5E); (iii) the region from 1300 to $900 \mathrm{~cm}^{-1}$ (Fig. 5B); (iv) the region from 900 to $600 \mathrm{~cm}^{-1}$ (Fig. 5C); and (v) the region from 600 to $40 \mathrm{~cm}^{-1}$ (Fig. 5D). Since there are not theoretical bands in the region from 2700 to $1300 \mathrm{~cm}^{-1}$, it will be described separately after the analysis of the four main regions.

3.5.1. OH stretching vibrations region. In Fig. 5A, the experimental and theoretical Raman spectra of the $\mathrm{OH}$ bond stretching region are displayed. Although the computed bands are displaced with respect to the experimental bands, the shape of the computed spectrum is consistent with the shape of the experimental spectrum and the correspondence between the bands of both spectra is clear. The Raman spectrum within this region displays three bands denoted as a, b and $\mathrm{c}$. The band $\mathrm{a}$ is resolved in two single band contributions located at 3510 and $3505 \mathrm{~cm}^{-1}$ and the bands $\mathrm{b}$ and $\mathrm{c}$ are found at 3419 and $2827 \mathrm{~cm}^{-1}$, respectively. All these bands are assigned to $\mathrm{OH}$ bond stretching vibrations.
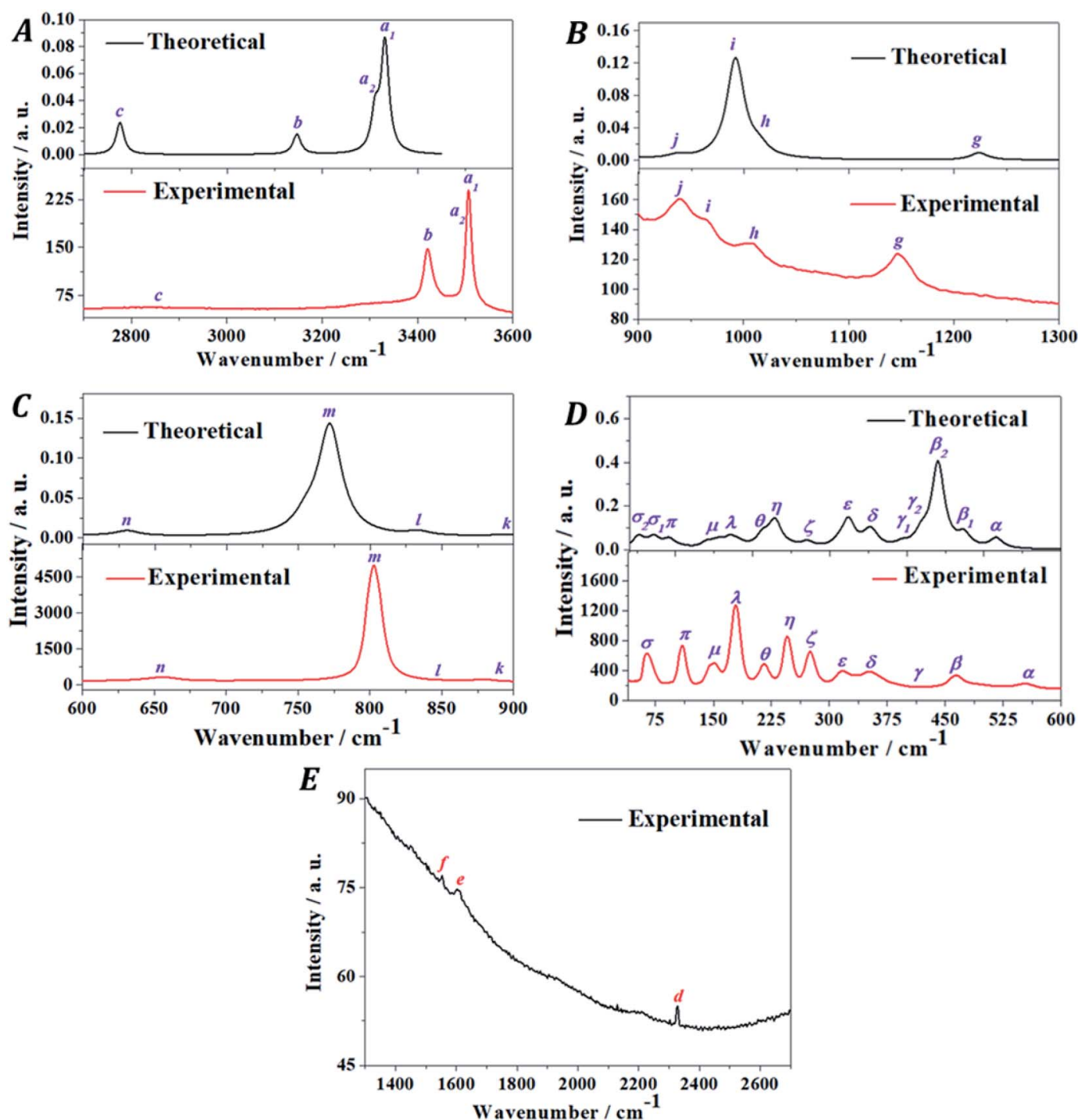

Fig. 5 Experimental and theoretical Raman spectra of vandenbrandeite: (A) region: $3600-2700 \mathrm{~cm}^{-1}$; (B) region: $1300-900 \mathrm{~cm}^{-1}$; (C) region: 900-600 $\mathrm{cm}^{-1}$; (D) region: $600-40 \mathrm{~cm}^{-1}$; (E) region: $2700-1300 \mathrm{~cm}^{-1}$. 
Table 4 Experimental and calculated Raman shifts of vandenbrandeite and calculated intensities and assignments

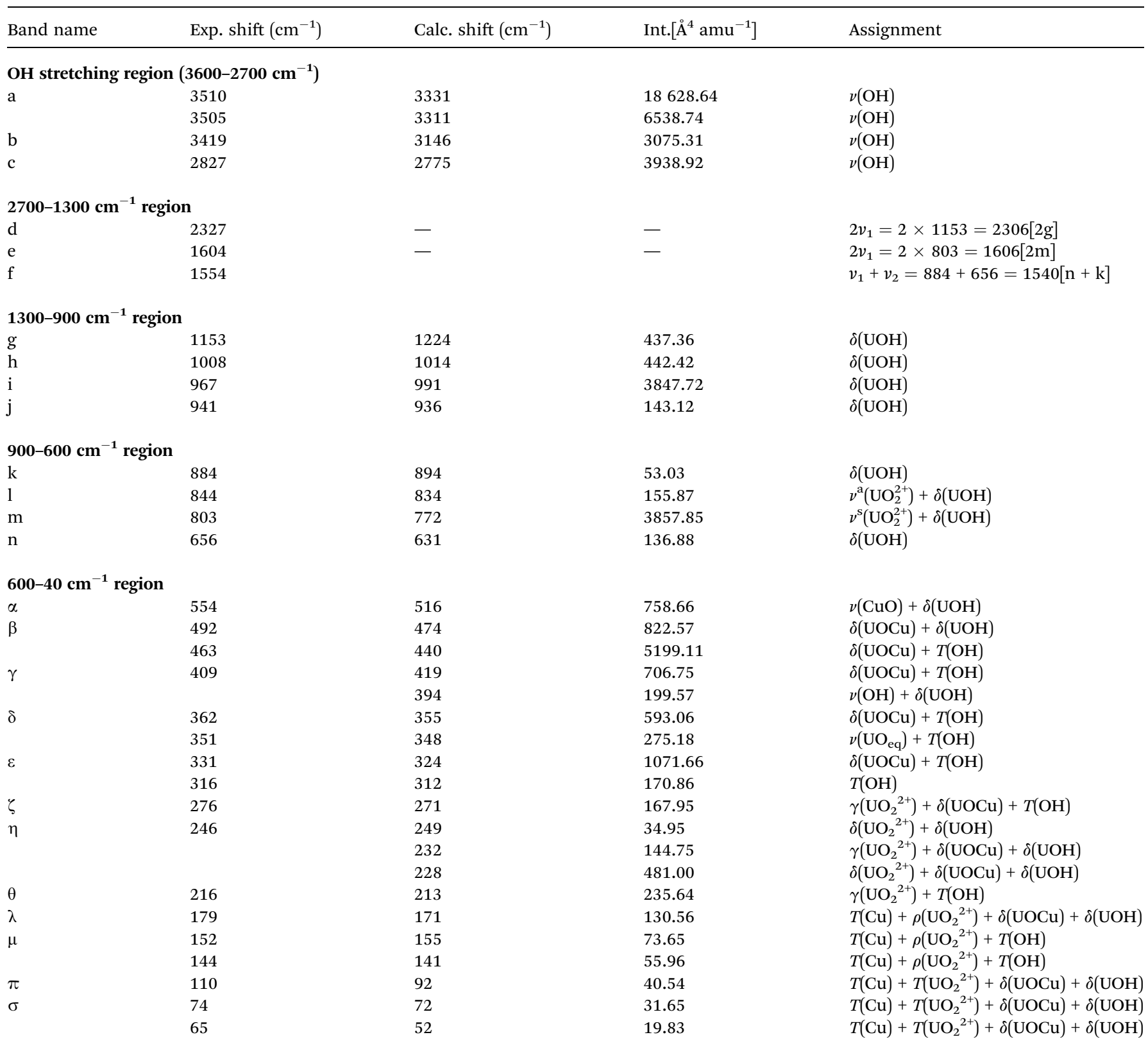

3.5.2. The 1300-900 $\mathrm{cm}^{-1}$ region. This Raman spectrum within this region (Fig. 5B) contains four main bands, referred to as $\mathrm{g}, \mathrm{h}, \mathrm{i}$ and $\mathrm{j}$, located at 1153, 1008, 967 and $941 \mathrm{~cm}^{-1}$, respectively, which are reproduced by the theoretical calculations at 1224, 1004, 991 and $936 \mathrm{~cm}^{-1}$, respectively. The four bands must be ascribed $\mathrm{UOH}$ bending vibrations.

3.5.3. The $900-600 \mathrm{~cm}^{-1}$ region. The weak band $\mathrm{k}$, at $884 \mathrm{~cm}^{-1}$, is satisfactorily calculated to be at $894 \mathrm{~cm}^{-1}$. This band is attributed $\mathrm{UOH}$ bending vibrations. The second band within this region (1), placed at $844 \mathrm{~cm}^{-1}$, is reproduced theoretically at $834 \mathrm{~cm}^{-1}$ and is assigned to a combination of uranyl antisymmetric stretching vibrations, $\nu^{\mathrm{a}}\left(\mathrm{UO}_{2}{ }^{2+}\right)$, and $\mathrm{UOH}$ bending vibrations. The very intense band $\mathrm{m}$, at $803 \mathrm{~cm}^{-1}$ has its theoretical counterpart at $772 \mathrm{~cm}^{-1}$. It is assigned to uranyl symmetric stretching vibrations, $\nu^{\mathrm{s}}\left(\mathrm{UO}_{2}{ }^{2+}\right)$, and $\mathrm{UOH}$ bending vibrations. Finally, the band $\mathrm{n}$, located at $656 \mathrm{~cm}^{-1}$ and reproduced theoretically at $631 \mathrm{~cm}^{-1}$, is ascribed to UOH bending vibrations only.

3.5.4. The $600-40 \mathrm{~cm}^{-1}$ region. The band $\alpha$, at $556 \mathrm{~cm}^{-1}$ corresponds to the calculated one located at $516 \mathrm{~cm}^{-1}$ and assigned to a combination of $\mathrm{CuO}$ bond stretching vibrations and $\mathrm{UOH}$ bending vibrations. Band $\alpha$ is composed of two subbands located at 492 and $463 \mathrm{~cm}^{-1}$ (see Fig. S.5.A of the ESI $\dagger$ ). These sub-bands are faithfully reproduced theoretically at 474 and $440 \mathrm{~cm}^{-1}$. The first band is assigned to $\mathrm{UOCu}$ and $\mathrm{UOH}$ bending vibrations and the second one to UOCu bending vibrations and hydroxyl translations. Likewise, the band $\gamma$, at $406 \mathrm{~cm}^{-1}$, corresponds to two theoretical bands located at 419 
and $394 \mathrm{~cm}^{-1}$. The first band is attributed to UOCu bending vibrations and hydroxyl translations and the last one to $\mathrm{OH}$ bond stretching vibrations and $\mathrm{UOH}$ bending vibrations. The band $\delta$ (see Fig. S.5.B of the ESI $\dagger$ ) comprises two sub-bands at 362 and $351 \mathrm{~cm}^{-1}$. These component bands are replicated theoretically at 355 and $348 \mathrm{~cm}^{-1}$, the first being ascribed to $\mathrm{UOCu}$ and $\mathrm{UOH}$ bending vibrations and the second one to equatorial UO bond stretching vibrations and hydroxyl translations. The band $\varepsilon$ has two component bands at 331 and $316 \mathrm{~cm}^{-1}$ which are positioned in the theoretical spectrum at 324 and $312 \mathrm{~cm}^{-1}$. The first of these bands is attributed to a combination of UOCu bending vibrations and hydroxyl translations and the second one to hydroxyl translations only.

The band $\xi$, located at $276 \mathrm{~cm}^{-1}$, is calculated to be at $271 \mathrm{~cm}^{-1}$ and assigned to uranyl deformations, UOCu bending vibrations and hydroxyl translations. Band $\eta$, at $246 \mathrm{~cm}^{-1}$, corresponds to the three close theoretical bands at 249 and 232 and $228 \mathrm{~cm}^{-1}$. The first of these bands is assigned to uranyl deformations and $\mathrm{UOH}$ bending vibrations. The second one is ascribed to uranyl deformations and $\mathrm{UOCu}$ and $\mathrm{UOH}$ bending vibrations. The assignment of the third sub-band is the same as that of the $232 \mathrm{~cm}^{-1}$ band but uranyl deformations are replaced by uranyl bending vibrations. The band $\theta$, at $216 \mathrm{~cm}^{-1}$, is very well reproduced theoretically at $2123 \mathrm{~cm}^{-1}$ and assigned to uranyl deformations and hydroxyl translations.

All the bands with lower wavenumbers in the Raman spectrum of vandenbrandeite $(\lambda, \mu, \pi$ and $\sigma$ ) contain contributions from copper atom translations. The band $\lambda$ at $179 \mathrm{~cm}^{-1}$ appears in the computed spectrum at $171 \mathrm{~cm}^{-1}$ and must be assigned to uranyl rotations, UOCu bending vibrations and cooper and hydroxyl translations. The band $\mu$ is composed of two subbands at 152 and $144 \mathrm{~cm}^{-1}$ which are reproduced theoretically at 155 and $141 \mathrm{~cm}^{-1}$. Both bands are ascribed to uranyl rotations and cooper and hydroxyl translations. The band $\pi$, at $110 \mathrm{~cm}^{-1}$, is calculated to be at $92 \mathrm{~cm}^{-1}$ and it is assigned to cooper, uranyl and hydroxyl translations and UOCu bending vibrations. Finally the band $\sigma$, contains two contributing subbands at 74 and $65 \mathrm{~cm}^{-1}$ which are reproduced theoretically at 72 and $52 \mathrm{~cm}^{-1}$, respectively. The two components of band $\sigma$ have the same assignment as band $\pi$.

The deformation $(\gamma)$, bending $(\delta)$ and rotation $(\rho)$ motions of the nearly linear uranyl cation appear in the assignments of the different bands of the low wavenumber region of the Raman spectrum of vandenbrandeite. Therefore, this spectral region should not be referred to as the uranyl bending region as it has been frequently denoted. The same was observed in the Raman spectrum of other uranyl minerals. The distinction between these motions was very clearly explained in a previous work. ${ }^{\mathbf{1 1 7}}$ The bending and rotation motions involve displacements of the uranyl oxygens out of the uranyl axis in the same and opposite directions, respectively. In the deformation motion, each oxygen displaces in a different direction.

It must be noticed that while the distribution of intensities in the $600-40 \mathrm{~cm}^{-1}$ region of the computed and experimental Raman spectra (Fig. 5D) is quite different, the matching of the wavenumbers of the peaks of both spectra is very good and faultless and, therefore, the assignment of the bands of this region should be reliable.

3.5.5. The $2700-1300 \mathrm{~cm}^{-1}$ region. Although there are not bands in the theoretical Raman spectrum of vandenbrandeite from 1300 to $2700 \mathrm{~cm}^{-1}$, a detailed examination of the experimental spectrum within this region shows the presence of three low intensity bands located at 2327 (d), 1604(e) and 1554 (f) $\mathrm{cm}^{-1}$ (see Fig. 5E). The bands $\mathrm{d}$ and e are recognized as overtone bands and the band $\mathrm{f}$ is identified as a combination band, as detailed in Table 4 .

\subsection{Thermodynamics}

3.6.1. Fundamental thermodynamic properties. The Fig. 6A, B, C and D display the computed isobaric specific heat $\left(C_{\mathrm{p}}\right)$, entropy $(S)$, enthalpy $(H)$ and Gibbs free energy $(G)$ functions of vandenbrandeite, respectively. The enthalpies and Gibbs free energies were divided by the temperature to express these properties employing the same units as for the specific heats and entropies $\left(\mathrm{J} \mathrm{K}^{-1} \mathrm{~mol}^{-1}\right)$. The detailed values of the calculated thermodynamic functions over the temperature range from 0 to $1000 \mathrm{~K}$ are reported in Tables S.4 to S.7 of the ESI. $\dagger$ The fundamental thermodynamic functions of vandenbrandeite have never been measured experimentally and, therefore, their values are reported in this work for the first time. The calculated specific heat at $1000 \mathrm{~K}$, the largest temperature considered, is $259.7 \mathrm{~J} \mathrm{~K}^{-1} \mathrm{~mol}^{-1}$, which is $13.2 \%$ below the Dulong-Petit asymptotic limit, 299.31 $\mathrm{J} \mathrm{K}^{-1} \mathrm{~mol}^{-1}$.

The calculated specific heat and entropy of vandenbrandeite at $298.15 \mathrm{~K}$ are 179.8 and $199.6 \mathrm{~J} \mathrm{~K}^{-1} \mathrm{~mol}^{-1}$, respectively. An accuracy of about 3-5\% may be expected for the calculated specific heat and entropy at room temperature. The expected accuracy was estimated in a previous work ${ }^{\mathbf{1 2 5}}$ from the analysis of the results obtained for uranyl-containing materials using the same methods as in this work in the cases in which the corresponding experimental values were available. The fundamental thermodynamic properties of several non-uranyl containing materials, as natroxalate and oxammite minerals and solid squaric acid, ${ }^{\mathbf{1 9 4 - 1 9 6}}$ were also determined utilizing the same methods as in the present work and the results were found to be within the above mentioned expected accuracy. The dependence of thermodynamic properties on the temperature is also expected to be accurately reproduced. For example, the computed specific heats and entropies of $\gamma-\mathrm{UO}_{3}$ were in excellent agreement with their experimental counterparts in the temperature range from 0 to $1000 \mathrm{~K} \cdot{ }^{\mathbf{1 2 3 , 1 2 4}}$ The differences of the calculated and experimental values of $C_{\mathrm{p}}$ and $S$ were $3.9 \%$ and $1.8 \%$ at $100 \mathrm{~K}$ and $6.1 \%$ and $3.6 \%$ at $1000 \mathrm{~K}$, respectively.

3.6.2. Thermodynamic properties of formation. Since the standard enthalpy of formation of vandenbrandeite has not been measured experimentally, its value was estimated using an approximate method originally due to Tardy and Garrels ${ }^{\mathbf{1 9 7}}$ and later developed by Finch $^{\mathbf{1 9 8}}$ and Ewing et al. ${ }^{\text {199,200 }}$ Using this method we obtained, $\Delta_{\mathrm{f}} H^{0}=-1998.1 \pm 10 \mathrm{~kJ} \mathrm{~mol}^{-1}\left(\Delta_{\mathrm{f}} G^{0}=\right.$ $-1771.3 \mathrm{~kJ} \mathrm{~mol}^{-1}$ ), where the error estimate is a conservative value resulting from the analysis of the values of the differences between the observed and estimated values in a set of cases in 

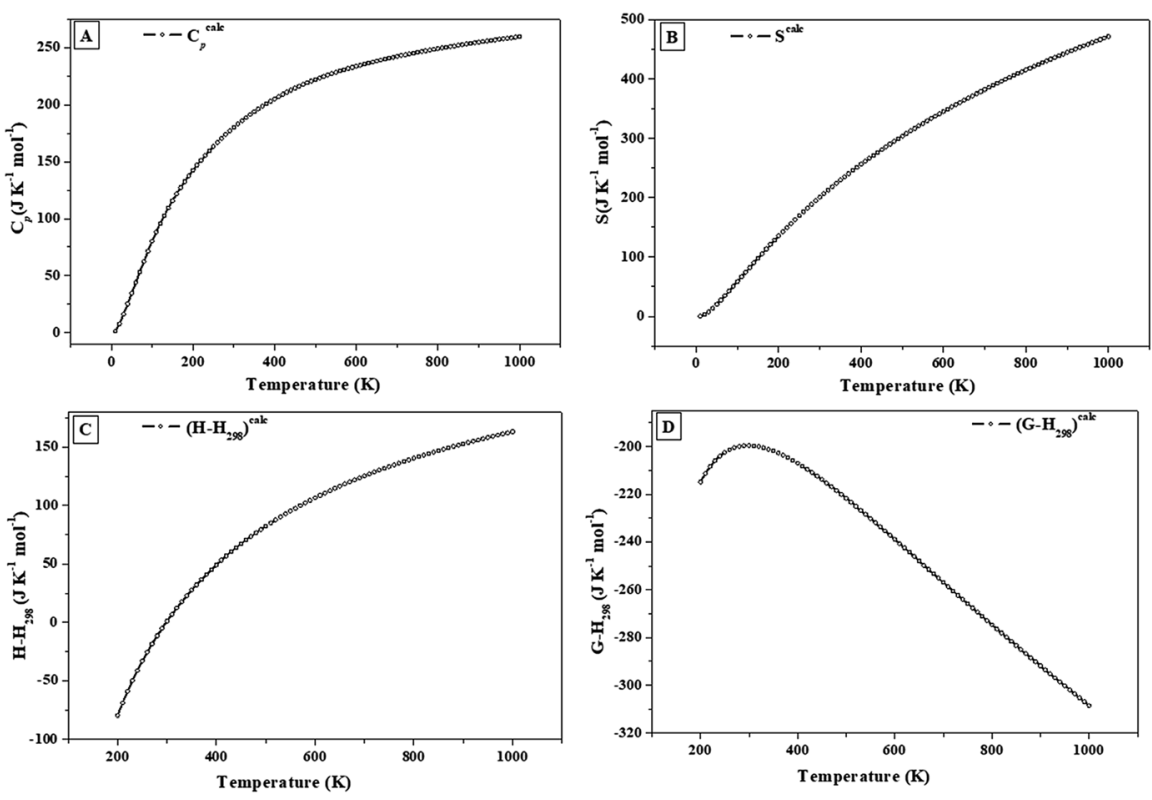

Fig. 6 Calculated heat capacity, entropy, enthalpy and free energy functions of vandenbrandeite: (A) isobaric heat capacity; (B) entropy; (C) enthalpy; (D) Gibbs free energy.

which the experimental values are known. The enthalpies and free energies of formation of vandenbrandeite in terms of the elements as a function of temperature were determined from this value of $\Delta_{\mathrm{f}} H^{0}$, the computed fundamental thermodynamic functions of vandenbrandeite and the experimental thermodynamic properties of the elements $\mathrm{Cu}, \mathrm{O}$ and $\mathrm{H}$ from Chase et al. ${ }^{180}$ and those of $\mathrm{U}$ from Barin. ${ }^{181}$ The computed values are given in Table 5. The Gibbs free energy of formation as a function of temperature is displayed in Fig. S.6 of the ESI. $\dagger$ If the experimental value of $\Delta_{\mathrm{f}} H^{0}$ of vandenbrandeite is accurately determined from experimental measurements in the future, the full temperature dependent thermodynamic properties of formation can be reevaluated directly by subtracting the estimated value from the values given in Table 5 and adding the

Table 5 Calculated enthalpies $\left(\Delta_{f} H\right)$ and free-energies $\left(\Delta_{f} G\right)$ of formation and associated reaction constants ( $\log K$ ) of vandenbrandeite as a function of temperature. The values of $\Delta_{\mathrm{f}} H$ and $\Delta_{\mathrm{f}} G$ are in units of $\mathrm{kJ} \mathrm{mol}^{-1}$

\begin{tabular}{lllr}
\hline$T(\mathrm{~K})$ & $\Delta_{\mathrm{f}} H$ & $\Delta_{\mathrm{f}} G$ & $\log K$ \\
\hline 298.15 & -1998.10 & -1771.30 & 310.32 \\
300 & -1997.35 & -1769.11 & 308.02 \\
350 & -1980.70 & -1713.77 & 255.76 \\
400 & -1969.30 & -1664.10 & 217.30 \\
450 & -1961.70 & -1618.60 & 187.88 \\
500 & -1956.98 & -1576.30 & 164.67 \\
540 & -1952.69 & -1544.11 & 149.36 \\
600 & -1953.96 & -1498.79 & 130.48 \\
650 & -1954.89 & -1462.74 & 117.54 \\
700 & -1957.11 & -1428.09 & 106.56 \\
750 & -1960.41 & -1394.62 & 97.13 \\
800 & -1964.66 & -1362.18 & 88.94
\end{tabular}

new experimental value. The theoretical thermodynamic functions of formation and their temperature dependence are expected to be accurate within about $3 \%$. This estimate of the expected accuracy was also obtained in a previous work ${ }^{125}$ from the analysis of the thermodynamic functions of formation obtained using the same theoretical methodology used here for uranyl containing materials for which experimental data was available.

3.6.3. Thermodynamic properties of the reactions (A) to (D). The computed thermodynamic functions of formation of vandenbrandeite, given in the previous section, were combined with those of gamma uranium trioxide, dehydrated schoepite, rutherfordine and soddyite, reported in a previous work, ${ }^{121}$ to study the reactions (A) to (D) given in the Introduction section. These reactions represent the formation of vandenbrandeite in terms of the corresponding oxides and the transformations of dehydrated schoepite, rutherfordine and soddyite minerals into vandenbrandeite, respectively. The experimental thermodynamic data for the non-uranyl containing materials involved in these reactions were taken from JANAF tables. ${ }^{180}$ The results are given in Table S.8 of the ESI $\dagger$ and plotted in Fig. 7.

From the results (see Fig. 7A), it follows that vandenbrandeite becomes unstable with respect to the corresponding oxides approximately at $116^{\circ} \mathrm{C}(390 \mathrm{~K})$. The calculations predict (Fig. 7B) that dehydrated schoepite will transform, in the presence of copper oxide, into vandenbrandeite up to $83{ }^{\circ} \mathrm{C}(356 \mathrm{~K})$. As shown in Fig. 7C, under the presence of carbon dioxide, vandenbrandeite should transform into rutherfordine within the full range of temperatures considered (300 to $500 \mathrm{~K}$ ). Similarly (Fig. 7D), from 300 to $500 \mathrm{~K}$, vandenbrandeite should transform into soddyite in the presence of silicon dioxide (quartz). If both carbon dioxide and silicon dioxide are simultaneously present, vandenbrandeite should transform into 

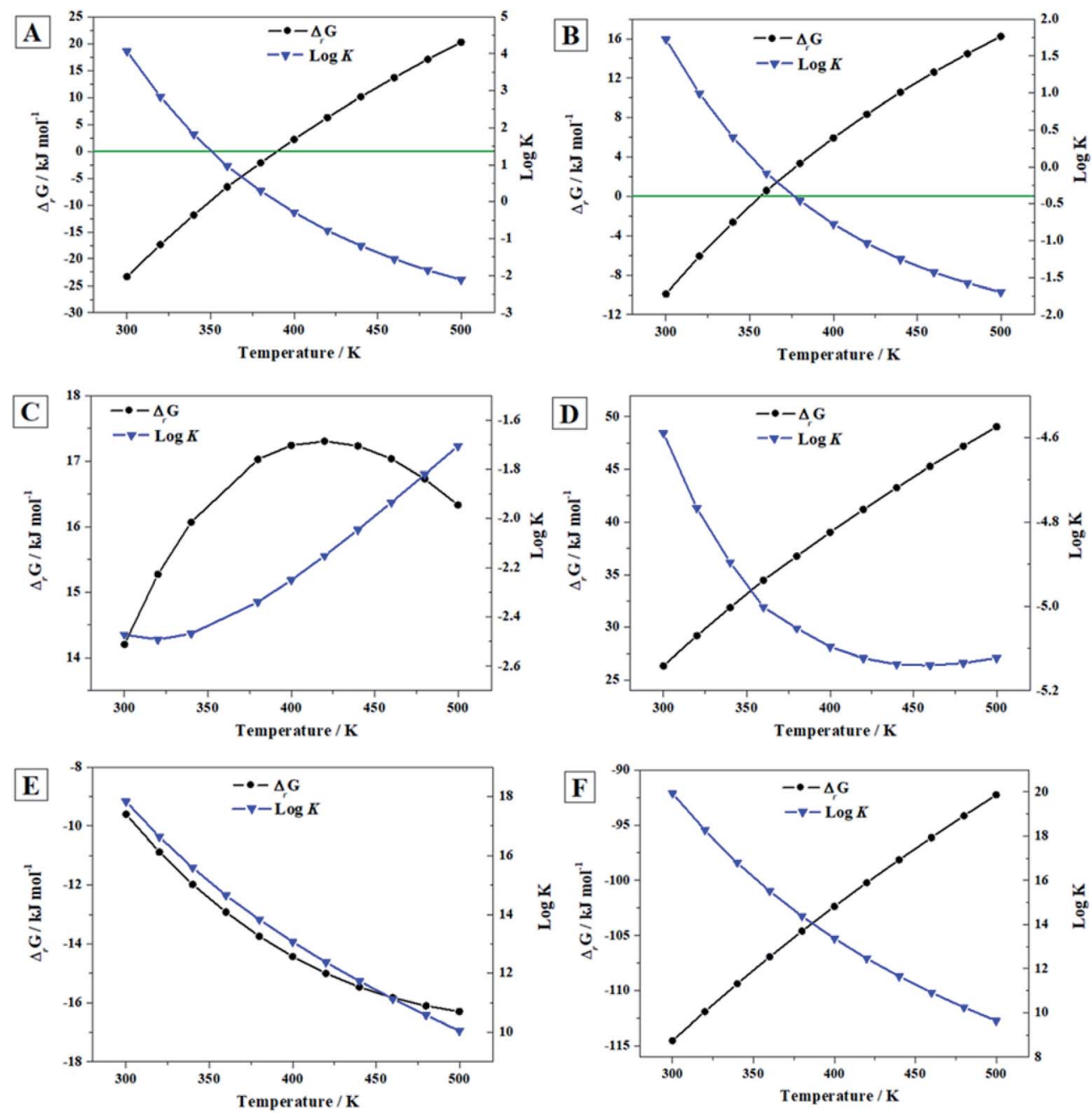

Fig. 7 Calculated free energies of reaction and associated reaction constants of reactions $(A)-(F)$ as a function of temperature.

soddyite because the Gibbs free energy of reaction (D) is larger than that of reaction (C) at all the temperatures.

These thermodynamic relations, being very useful and rigorous, must be interpreted and used with caution. A full evaluation and understanding of the number and relative amount of the secondary phases of spent nuclear fuel present at the conditions of a final geological disposal over time requires the realization of complete thermodynamic computations ${ }^{124,125,201-204}$ employing thermochemical data for a significant number of materials, including the most important secondary phases, amorphous phases and aqueous species, at a wide range of temperature and pressure conditions. For example, the presence of oxidant species as hydrogen peroxide (see next section) and their concentration alters drastically the relative stability of the secondary phases of the SNF.

3.6.4. Thermodynamic properties of reactions (E) and (F). As in the previous section, the calculated thermodynamic properties of formation of vandenbrandeite were merged with those of schoepite and studtite minerals reported in previous works ${ }^{115,121}$ to study the reactions (E) and (F) provided in the Introduction section. The reaction (E) represents the transformation of vandenbrandeite into schoepite in the presence of water and hydrogen peroxide and the reaction $(\mathrm{F})$ represents the corresponding transformation into studtite in the presence of hydrogen peroxide and absence of water. The last situation is important because is the one expected under intense radiation fields causing the radiolysis of most of the water reaching the surface of the spent nuclear fuel. The thermodynamic experimental data for the non-uranyl systems needed to determine the enthalpies and Gibbs free energies of these reactions were taken from JANAF tables, ${ }^{180}$ except those of hydrogen peroxide, which were taken from Barin. ${ }^{181}$ The results are given in Table S.8 (ESI $\dagger$ ) and displayed in Fig. 7. Liquid hydrogen peroxide is thermodynamically stable up to $500 \mathrm{~K},{ }^{181}$ the larger temperature for which the thermodynamic properties of reactions (E) and (F) have been determined.

Since the Gibbs free energies and enthalpies of reaction (E) are negative everywhere (see Fig. 7E), the reaction of conversion of vandenbrandeite into schoepite under the presence of water and hydrogen peroxide is spontaneous and exothermic from 300 to $500 \mathrm{~K}$. This is due to the great thermodynamic stability of schoepite at these conditions. ${ }^{115}$ The same is true for reaction 
(F) as shown in Fig. 7F. Hence, vandenbrandeite phase will be converted into studtite under high hydrogen peroxide concentrations. Although vandenbrandeite, as it occurred with schoepite, metaschoepite and becquerelite uranyl oxide hydrate phases, ${ }^{115,116}$ is largely stabilized under high concentrations of hydrogen peroxide, its stabilization under these conditions is not as large as that of studtite phase. ${ }^{124}$ Kubatko et al. ${ }^{205}$ and Forbes et $a .^{206}$ observed experimentally that becquerelite, dehydrated schoepite and soddyite transform readily into studtite in the presence of high concentrations of hydrogen peroxide. The transformation of uranium trioxide, rutherfordine, metastudtite, schoepite and metaschoepite and becquerelite into studtite was also predicted in previous works. ${ }^{115,116,124,125}$ Vandenbrandeite should also transform into studtite under these conditions.

3.6.5. Relative thermodynamic stability of vandenbrandeite with respect to other secondary phases of the spent nuclear fuel. Using the present thermodynamic data and those reported in previous works ${ }^{115,116,124,125}$ the order of stability of vandenbrandeite, uranosphaerite, becquerelite, schoepite, metaschoepite, dehydrated schoepite, studtite, metastudtite, soddyite, rutherfordine and $\gamma-\mathrm{UO}_{3}$ may be evaluated: (A) in the absence of hydrogen peroxide; (B) in the presence of water and hydrogen peroxide; and (C) in the presence of high hydrogen peroxide concentrations. The relative stability of these phases at these conditions in the range of temperatures from 300 to $500 \mathrm{~K}$ is plotted in Fig. 8. The relative thermodynamic stabilities displayed in Fig. 8A, B and C are determined with respect to $\gamma-\mathrm{UO}_{3}$, metastudtite and studtite, respectively.

Fig. 8A shows that, in the absence of hydrogen peroxide, soddyite is the most stable phase and that rutherfordine and becquerelite (the second and third most stable phases at $300 \mathrm{~K}$ ) are also more stable than vandenbrandeite. Thus, at hydrogen peroxide free conditions, vandenbrandeite should be replaced by other mineral phases in the presence of, for example, silicate or carbonate ions. The uranyl oxide hydrate phases (Fig. 8B) are stabilized by the presence of water and hydrogen peroxide. The same appears to occur with the uranyl-copper tetrahydroxide phase. As shown in Fig. 8B, under the presence of water and hydrogen peroxide, vandenbrandeite becomes the second most stable phase after schoepite (becquerelite becomes more stable than vandenbrandeite at $373 \mathrm{~K}$ ). Fig. $8 \mathrm{~B}$ shows that in the presence of water and hydrogen peroxide, there is a large stability gap between schoepite, vandenbrandeite, metaschoepite and becquerelite minerals and the remaining ones. Finally, in the presence of high hydrogen peroxide concentrations (Fig. 8C), the stability of vandenbrandeite also increases as it also occurs to studtite, schoepite, metaschoepite and becquerelite. ${ }^{114,115,124}$ Under high concentrations of hydrogen peroxide, studtite becomes by far the most stable phase. Vandenbrandeite becomes the fourth most stable phase among those considered in this work and again there is a large stability gap between studtite, schoepite, metaschoepite, vandenbrandeite and becquerelite and the remaining phases under study.
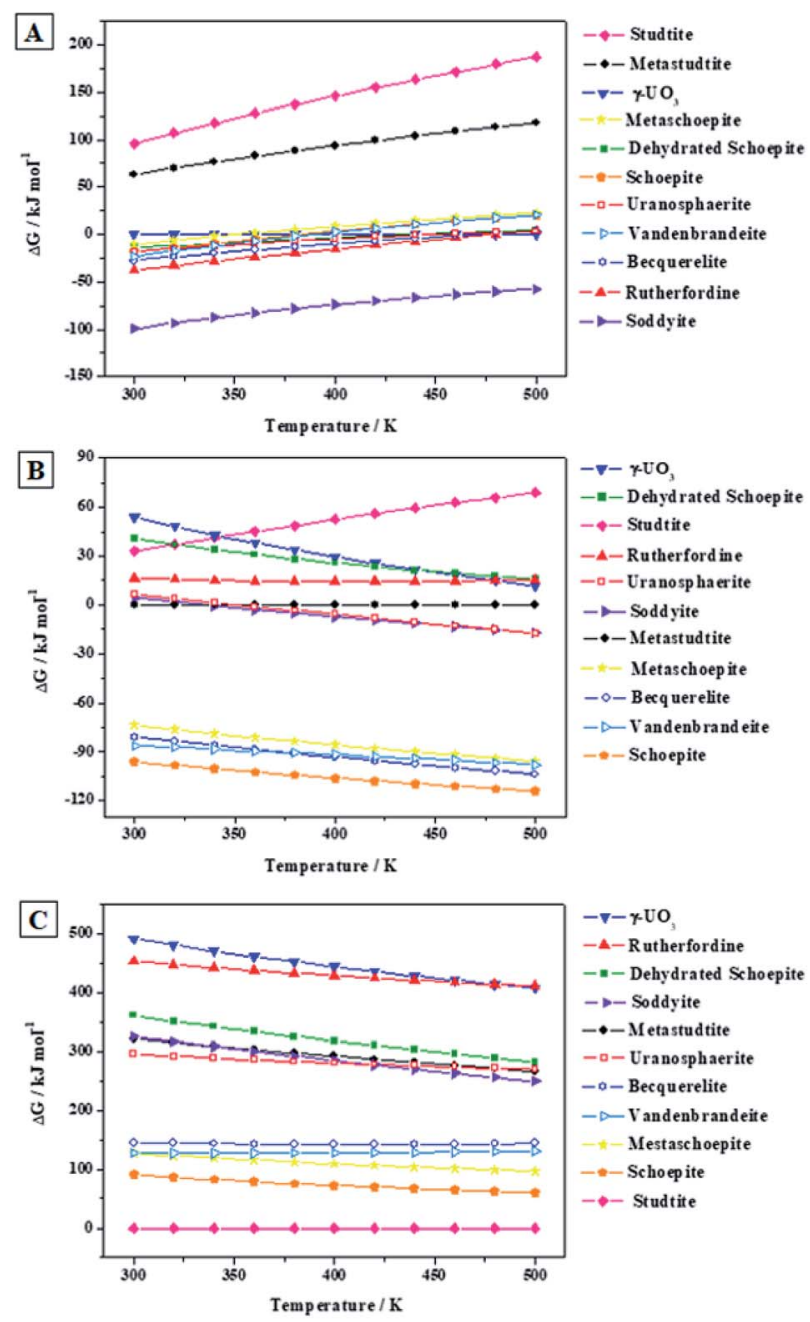

Fig. 8 Relative thermodynamic stability of vandenbrandeite with respect to other secondary phases of SNF: (A) under the absence of hydrogen peroxide; (B) under the presence of water and hydrogen peroxide; (C) under high concentrations of hydrogen peroxide. The labels of the different phases are ordered vertically according to their relative stability at $300 \mathrm{~K}$.

\section{Conclusions}

A complete characterization of the crystal structure, the Raman spectrum and the mechanical and thermodynamic properties of the copper-uranyl tetrahydroxide mineral vandenbrandeite has been achieved by means of the X-ray diffraction and infrared and Raman spectroscopy techniques combined with first principles solid-state methods. The full crystal structure of vandenbrandeite, including the positions of the hydrogen atoms is obtained by the first time from X-ray diffraction data by structure refinement. Furthermore, the computed crystal structure is confirmed theoretically since the computed unit-cell parameters, interatomic distances and angles and X-ray diffraction pattern of vandenbrandeite are in excellent agreement with the experimental data. The availability of the full energy-optimized crystal structure of vandenbrandeite made possible the computation of its mechanical properties, Raman spectrum 
and thermodynamic properties using the first-principles methodology. We conclude that the first-principles methods provided a faithful description of vandenbrandeite crystal structure and spectra at the nanometer scale and allowed to determine a significant amount of relevant material properties whose accurate determination by means of experimental methods could be extremely difficult.

From the computed elasticity matrix, equation of state and phonon spectra, the mechanical and dynamical stability of the crystal structure of vandenbrandeite were stablished and a rich set of relevant elastic properties were derived. This set comprises the bulk, shear and Young moduli, ductility, hardness and universal anisotropy indices and the derivatives of the bulk modulus with respect to pressure. The Raman spectrum of vandenbrandeite was recorded from a natural crystal sample and was also determined using density functional perturbation theory. The computed and experimental spectra have a very high degree of consistence and, therefore, all the Raman bands were rigorously assigned using a normal coordinate analysis of the theoretical vibrational results. The Raman spectrum within the spectral region from 1300 to $2700 \mathrm{~cm}^{-1}$ was shown to contain three low intensity bands. Two of these bands were recognized as overtones and the other one as a combination band.

From accurate phonon calculations, the fundamental thermodynamic properties of vandenbrandeite were evaluated. These thermodynamic properties were then used to determine the thermodynamic properties of formation of vandenbrandeite in terms of the elements as a function of temperature. In turn, the thermodynamic functions of formation were employed in order to obtain the Gibbs free energies of reaction and the associated reaction constants of a series of reactions involving vandenbrandeite and a representative subset of the most important secondary phases of spent nuclear fuel. The relative stability of vandenbrandeite with respect to these phases as a function of temperature and under different concentrations of hydrogen peroxide was reported. It was found that vandenbrandeite is strongly stabilized under the presence of hydrogen peroxide and that, under the simultaneous presence of water and hydrogen peroxide, becomes the second most stable phase among those considered in this work after schoepite.

\section{Conflicts of interest}

There are no conflicts of interest to declare.

\section{Acknowledgements}

The supercomputer time provided by the CTI-CSIC center is greatly acknowledged. This work has been carried out in the context of a CSIC-CIEMAT collaboration agreement: "Caracterización experimental y teórica de fases secundarias y óxidos de uranio formados en condiciones de almacenamiento de combustible nuclear”. JP acknowledges the support through the project no. LO1603 of the Ministry of Education, Youth and Sports National Sustainability Program I of the Czech Republic. JS and JČ were supported by the Ministry of Culture of the Czech
Republic (long-term project DKRVO 2019-2023/1.II.a and 1.II.b; National Museum, 00023272). VT was supported by the Ministry of Science, Innovation and Universities within the Project FIS2016-77726-C3-1-P. VP thanks the support from the Czech Science Foundation (project 18-10504S).

\section{References}

1 Swedish Corrosion Institute, Copper as canister material for unreprocessed nuclear waste - evaluation with respect to corrosion, Report KBS-TR-90, Swedish Nuclear Fuel Supply Company, Stockholm, 1978.

2 G. Hultquist, Corros. Sci., 1986, 26, 173.

3 T. E. Eriksen, P. Ndalgmba and I. Grenthe, Corros. Sci., 1989, 29, 1241.

4 P. Wersin, K. Spahiu and J. Bruno, Kinetic modelling of bentonite-canister interaction. Long-term predictions of copper canister corrosion under oxic and anoxic conditions, Technical Report SKB-TR-94-25, Swedish Nuclear Fuel and Waste Management Company, Stockholm, 1994.

5 R. Sjoblom, H. P. Hermansson and O. Amcoff, Mater. Res. Soc. Symp. Proc., 1995, 353, 687.

$6 \mathrm{H}$. P. Hermansson and S. Eriksson, Corrosion of the Copper Canister in the Repository Environment, SKI Report 99:52, Swedish Nuclear Power Inspectorate (SKI), Stockholm, 1999.

7 A. E. Mildowski, M. T. Styles and V. L. Hards, A natural analogue for copper waste canisters: the copper-uranium mineralised concretions in the Permian mudrocks of south Devon, United Kingdom, Technical Report SKB-TR-00-11, Swedish Nuclear Fuel and Waste Management Company, Stockholm, 2000.

8 A. E. Mildowski, M. T. Styles, M. S. A. Horstwood and S. J. Kemp, Alteration of uraniferous and native copper concretions in the Permian mudrocks of south Devon, United Kingdom, Technical Report SKB-TR-02-09, Swedish Nuclear Fuel and Waste Management Company, Stockholm, 2002.

9 F. King, L. Ahonen, C. Taxén, U. Vuorinen and L. Werme, Copper corrosion under expected conditions in a deep geologic repository, Technical Report SKB-TR-01-23, Swedish Nuclear Fuel and Waste Management Company, Stockholm, 2001.

$10 \mathrm{R}$. Gubner and U. Andersson, Corrosion resistance of copper canister weld material, Technical Report SKB-TR-07-07, Swedish Nuclear Fuel and Waste Management Company, Stockholm, 2007.

11 P. Szakálos, G. Hultquist and G. Wikmark, Electrochem. Solid-State Lett., 2007, 10, C63.

12 G. Hultquist, P. Szakálos, M. J. Graham, A. B. Belonoshko, G. I. Sproule, L. Gråsjö, P. Dorogokupets, B. Danilov, T. Aastrup, G. Wikmark, G. K. Chuah, J. C. Eriksson and A. Rosengren, Catal. Lett., 2009, 132, 311.

13 G. Hultquist, M. J. Graham, P. Szakálos, G. I. Sproule, A. Rosengren and L. Gråsjö, Corros. Sci., 2011, 53, 310.

14 B. Rosborg and L. Werme, J. Nucl. Mater., 2008, 379, 142.

15 B. Rosborg, Recorded corrosion rates on copper electrodes in the Prototype Repository at the Äspö HRL, Report SKB-R-13- 
13, Swedish Nuclear Fuel and Waste Management Company, Stockholm, 2013.

16 P. Wersin, LOT A2 test parcel. Compilation of copper data in the LOT A2 test parcel, Report TR-13-17, Swedish Nuclear Fuel and Waste Management Company, Stockholm, 2013.

17 S. Kärnbränslehantering, Design, production and initial state of the canister, Technical Report SKB-TR-10-14, Swedish Nuclear Fuel and Waste Management Company, Stockholm, 2014.

18 Å. Björkbacka, S. Hosseinpour, M. Johnson, C. Leygraf and M. Jonsson, Radiat. Phys. Chem., 2013, 92, 80.

19 G. Hultquist, Corros. Sci., 2015, 93, 327.

20 M. Ottossona, M. Bomana, P. Berasteguia, Y. Anderssona, M. Hahlina, M. Korvelab and R. Bergera, Corros. Sci., 2017, 122, 53.

21 A. Hedin, A. J. Johansson, C. Lilja, M. Boman, P. Berastegui, R. Berger and M. Ottosson, Corros. Sci., 2018, 137, 1.

22 N. Marcos, Mater. Res. Soc. Symp. Proc., 1997, 465, 1153.

23 F. King and P. Wersin, Review of Supercontainer Copper Shell-Bentonite Interactions and Possible Effects on Buffer Performance for the KBS-3H Design, Posiva Working Report 2013-03, Posiva, Olkiluoko, 2014.

24 P. Wersin, P. A. Epping, M. Pekala, P. Pitkänen and M. Snellman, Procedia Earth Planet. Sci., 2017, 17, 722.

25 P. Alt-Epping, M. Pekala, P. Wersin and P. Pitkänen, in Proceedings of the 7th International Conference on Clay in Natural and Engineered Barriers for Radioactive Waste Confinement, Davos, Switzerland, 2017, p. 50.

26 P. Wersin, M. Pękala, P. Alt-Epping, P. Pitkänen and V. Cloet, in Proceedings of the 16th International High-Level Radioactive Waste Management (IHLRWM 2017), Charlotte, NC, 2017, p. 30.

27 M. Pekala, P. Alt-Epping and P. Wersin, 3D and 1D DualPorosity Reactive Transport Simulations - Model Improvements, Sensitivity Analyses, and Results from the Integrated Sulfide Project Inter-Model Comparison Exercise, Posiva Working Report 2018-31, Posiva, Olkiluoko, 2019.

28 F. King and C. D. Litke, The corrosion of copper in synthetic groundwater at $150{ }^{\circ} \mathrm{C}$. Part I. The results of short term electrochemical tests, Technical Record TR-428, Atomic Energy of Canada Ltd. Toronto, 1987.

29 F. King, Appl. Geochem., 1995, 10, 477.

30 F. King, C. D. Litke, M. J. Quinn and D. M. LeNeveu, Corros. Sci., 1995, 37, 833.

31 K. Worgan, M. Apted and R. Sjoblom, Mater. Res. Soc. Symp. Proc., 1995, 353, 895.

32 F. King and M. Kolar, Theory manual for the copper corrosion model for stress corrosion cracking of used fuel disposal containers CCM-SCC.O, Nuclear Waste Management Division Report 06819-REP-01300-10095-R00, Ontario Power Generation, Toronto, Ontario, 2004.

33 F. King and M. Kolar, Simulation of the consumption of oxygen in long-term in situ experiments and in the third case study repository using the copper corrosion model CCMUC.1.1, Nuclear Waste Management Division Report 06819-REP-01300-10084-R00, Ontario Power Generation, Toronto, Ontario, 2006.
34 F. King, Review and gap analysis of the corrosion of copper containers under unsaturated conditions, Nuclear Waste Management Division Report 06819-REP-01300-10124R00, Ontario Power Generation, Toronto, Ontario, 2006.

35 J. M. Smith, The corrosion and electrochemistry of copper in aqueous, anoxic sulphide solutions, $\mathrm{PhD}$ Thesis, The University of Western Ontario, Canada, 2007.

36 J. Smith, Z. Qin, F. King, L. Werme and D. W. Shoesmith, Corrosion, 2007, 63, 135.

37 B. M. Ikeda and C. D. Litke, Stress corrosion cracking of copper in nitrite/chloride mixtures at elevated temperatures, Technical Report NWMO TR-2007-04, Nuclear Waste Management Organization, Toronto, Ontario, 2007.

38 F. King, M. Kolar and P. Maak, J. Nucl. Mater., 2008, 379, 133.

39 F. King, Corrosion, 2009, 65, 233.

40 G. M. Kwong, Status of corrosion studies for copper used fuel containers under low salinity conditions, NWMO Technical Report NWMO-TR-2011-14, Nuclear Waste Management Organization, Toronto, Canada, 2011.

41 J. Chen, Z. Qin and D. W. Shoesmith, Long-term corrosion of copper in a dilute anaerobic sulfide solution, Electrochim. Acta, 2011, 56, 7854.

42 F. King, C. Lilja and M. Vähänen, J. Nucl. Mater., 2013, 438, 228.

43 P. G. Keech, P. Vo, S. Ramamurthy, J. Chen, R. Jacklin and D. W. Shoesmith, Corros. Eng., Sci. Technol., 2014, 49, 425.

44 C. H. Boyle and S. A. Meguid, Nucl. Eng. Des., 2015, 293, 403.

45 T. Standish, J. Chen, R. Jacklin, P. Jakupi, S. Ramamurthy, D. Zagidulin, P. Keech and D. W. Shoesmith, Electrochim. Acta, 2016, 211, 331.

46 B. Ibrahim, D. Zagidulin, M. Behazin, S. Ramamurthy, J. C. Wren and D. W. Shoesmith, Corros. Sci., 2018, 141, 53.

47 J. P. Simpson, Experiments on container materials for Swiss high-level waste disposal projects Part II, Nagra Technical Report 84-01, National Cooperative for the Disposal of Radioactive Waste, Wettingen, 1984.

48 L. H. Johnson and F. King, Canister options for the disposal of spent fuel, NAGRA Technical Report 02-11, National Cooperative for the Disposal of Radioactive Waste, Wettingen, 2003.

49 JNC, Second Progress Report in Research and Development for the Geological Disposal of HLW in Japan, Supporting Report 2, Repository Design and Engineering Technology, Japan Nuclear Cycle Development Institute, 2000.

50 N. Taniguchi and M. Kawasaki, J. Nucl. Mater., 2008, 379, 154.

51 H. J. Choi, M. Lee and J. Y. Lee, Nucl. Eng. Des., 2010, 240, 2714.

52 B. Kursten, E. Smailos, I. Azkarate, L. Werme, N. R. Smart and G. Santarini, State-of-the-art document on the COrrosion BEhaviour of COntainer MAterials, COBECOMA project Final Report, 5th Euratom Framework Programme, Contract No. FIKW-CT-20014-20138, European Commission, 2004.

53 D. Landolt, R. H. Muller and C. W. Tobias, J. Electrochem. Soc., 1969, 116, 1385. 
54 A. L. Bacarella and J. C. Griess, J. Electrochem. Soc., 1973, 120, 459.

55 S. B. Adeloju and Y. Y. Duan, Br. Corros. J., 1994, 29, 309.

56 A. Fateh, M. Aliofkhazraei and A. R. Rezvanian, Arabian J. Chem., 2017, DOI: 10.2016/j.arabjc.2017.05.021.

57 S. Li, M. T. Teague, G. L. Doll, E. J. Schindelholz and H. Conga, Corros. Sci., 2018, 141, 243.

58 R. C. Ewing, Nat. Mater., 2015, 14, 252.

59 R. Wang and Y. B. Katayama, Nucl. Chem. Waste Manage., 1982, 3, 83 .

60 D. W. Shoesmith and S. Sunder, J. Nucl. Mater., 1992, 190, 20.

61 S. Sunder, D. W. Shoesmith, H. Christensen and N. H. Miller, J. Nucl. Mater., 1992, 190, 78.

62 D. W. Shoesmith, J. Nucl. Mater., 2000, 282, 1.

63 G. Sattonnay, C. Ardois, C. Corbel, J. F. Lucchini, M. F. Barthe, F. Garrido and D. Gosset, J. Nucl. Mater., 2001, 288, 11.

64 O. Roth and M. Jonsson, Cent. Eur. J. Chem., 2008, 6, 1.

65 H. Christensen and S. Sunder, J. Nucl. Mater., 1996, 238, 70. 66 J. Plášil, J. Geosci., 2014, 59, 99.

67 R. J. Finch and T. Murakami, Rev. Mineral. Geochem., 1999, 38, 91.

68 I. Grenthe, J. Drozdzynski, T. Fujino, E. C. Buck, T. E. Albrecht-Schmitt and S. F. Wolf, in The Chemistry of Actinide and Transactinide Elements, ed. L. R. Morss, N. M. Edelstein and J. Fuger, Springer Science and Business Media, Berlin, 2006, ch. V, vol. I; pp. 253-638.

69 S. V. Krivovichev and J. Plášil, in Uranium: From Cradle to Grave, ed. P. C. Burns and G. E. Sigmon, Mineralogical Association of Canada, Winnipeg, MB, Canada, 2013, short course 43, pp. 15-119.

70 P. C. Burns, R. C. Ewing and M. L. Miller, J. Nucl. Mater., 1997, 245, 1.

71 A. Rosenzweig and R. R. Ryan, Am. Mineral., 1975, 60, 448.

72 J. Plášil, Minerals, 2018, 8, 551.

73 P. Piret, J. Appl. Crystallogr., 1979, 12, 616.

74 T. A. Olds, J. Plášil, A. R. Kampf, F. Dal Bo and P. C. Burns, Minerals, 2018, 8, 511.

75 P. Piret, J. P. Declercq and D. Wauters-Stoop, Bull. Mineral., 1980, 103, 176.

76 J. Čejka, Z. Urbanec, J. Čejka Jr and Z. Mrázek, Neues Jahrb. Mineral., Abh., 1988, 159, 297.

77 P. Ondruš, F. Veselovský, R. Skála, I. Císařová, J. Hloušek, J. Frýda, Vavřín, J. Čejka and A. Gabašová, J. Czech Geol. Soc., 1997, 42, 7.

78 P. Ondruš, F. Veselovský, A. Gabašová, J. Hloušek and V. Šrein, J. Czech Geol. Soc., 2003, 48, 149.

79 J. Plášil, K. Fejfarová, K. S. Wallwork, M. Dušek, R. Škoda, J. Sejkora, J. Čejka, F. Veselovský, J. Hloušek, N. Meisser and J. Brugger, Am. Mineral., 2012, 97, 1796.

80 A. J. Locock and P. C. Burns, Can. Mineral., 2003, 41, 489.

81 W. D. Birch, W. D. Mumme and E. R. Segnit, Aust. Mineral., 1988, 3, 125.

82 U. Kolitsch and G. Giester, Mineral. Mag., 2001, 65, 717.

83 P. C. Burns, R. C. Ewing and F. C. Hawthorne, Can. Mineral., 1997, 35, 1551.
84 P. C. Burns, Rev. Mineral. Geochem., 1999, 38, 23.

85 P. C. Burns, Can. Mineral., 2005, 43, 1839.

86 P. C. Burns, J. Nucl. Mater., 1999, 265, 218.

87 P. C. Burns, K. M. Deely and S. Skanthakumar, Radiochim. Acta, 2004, 92, 151.

88 A. L. Klingensmith and P. C. Burns, Am. Mineral., 2007, 92, 1946.

89 C. Frondel, Am. Mineral., 1956, 41, 539.

90 R. M. Garrels and C. L. Christ, US Geol. Surv. Prof. Pap., 1959, 320, 81.

91 R. J. Finch and R. C. Ewing, J. Nucl. Mater., 1992, 190, 133.

92 R. J. Finch and R. C. Ewing, Uraninite alteration in an oxidizing environment and its relevance to the disposal of spent nuclear fuel, SKB Technical Report 91-15, Swedish Nuclear Fuel and Waste Management Co., Stockholm, Sweden, 1994.

93 R. S. Forsyth and L. O. Werme, J. Nucl. Mater., 1992, 190, 3. 94 E. C. Pearcy, J. D. Prikryl, W. M. Murphy and B. W. Leslie, Appl. Geochem., 1994, 9, 713.

95 D. J. Wronkiewicz, J. K. Bates, T. J. Gerding, E. Veleckis and B. S. Tani, J. Nucl. Mater., 1992, 190, 107.

96 D. J. Wronkiewicz, J. K. Bates, S. F. Wolf and E. C. Buck, J. Nucl. Mater., 1996, 238, 78.

97 J. Bruno, I. Casas, E. Cera, R. C. Ewing, R. J. Finch and L. O. Werme, Mater. Res. Soc. Symp. Proc., 1994, 353, 633.

98 P. A. Finn, J. C. Hoh, S. F. Wolf, S. A. Slater and J. K. Bates, Radiochim. Acta, 1996, 74, 65.

99 A. Schoep, Ann. Mus. Congo Belge, 1932, 1, 22.

100 J. Thoreau, Ann. Soc. Geol. Belge, 1931, 55, C3.

101 C. Frondel, U.S. Geol. Surv. Bull., 1958, 1064, 1.

102 G. Gauthier, A. François, M. Deliens and P. Piret, Mineral. Rec., 1989, 20, 265.

103 C. Bignand, Bull. Soc. Fr. Mineral. Cristallogr., 1955, 78, 1.

104 I. H. Milne and E. W. Nuffield, Am. Mineral., 1951, 36, 394.

105 A. Rosenzweig and R. R. Ryan, Cryst. Struct. Commun., 1977, 6, 53.

106 A. S. Povarennykh, Konstitut. Svoy. Mineral., 1979, 13, 78.

107 J. Čejka and Z. Urbanec, Trans. Czech. Acad. Sci., Math. Natur. Sci. Ser., 98, 1-93.

108 J. Čejka, Neues Jahrb. Mineral., Abh., 1994, H3, 112.

109 P. Škácha, J. Plášil, J. Sejkora, J. Čejka, R. Škoda and N. Meisser, Bull. Mineral. Petrolog. Odd. Nár. Muz., 2014, 22, 240.

110 J. Plášil, Eur. J. Mineral., 2018, 30, 253.

111 J. Plášil, Z. Kristallogr., 2019, 234, 733-738.

112 S. Ghazisaeed, B. Kiefer and J. Plášil, RSC Adv., 2019, 9, 10058.

113 F. Colmenero, J. Cobos and V. Timón, Inorg. Chem., 2018, $57,4470$.

114 F. Colmenero, A. M. Fernández, J. Cobos and V. Timón, ACS Earth Space Chem., 2019, 3, 17.

115 F. Colmenero, A. M. Fernández, J. Cobos and V. Timón, RSC Adv., 2019, 8, 24599.

116 F. Colmenero, J. Cobos and V. Timón, J. Phys.: Condens. Matter, 2019, 31, 175701.

117 F. Colmenero, J. Plášil, J. Cobos, J. Sejkora, V. Timón, J. Čejka and L. J. Bonales, RSC Adv., 2019, 9, 15323. 
118 F. Colmenero, J. Plášil and J. Sejkora, Dalton Trans., 2019, 48, 16722.

119 L. J. Bonales, F. Colmenero, J. Cobos and V. Timón, Phys. Chem. Chem. Phys., 2016, 18, 16575.

120 F. Colmenero, in Minerals, ed. K. S. Essa, InTechOpen, London, 2018, ISBN: 978-953-51-6784-6.

121 F. Colmenero, A. M. Fernández, J. Cobos and V. Timón, J. Phys. Chem. C, 2018, 122, 5254.

122 F. Colmenero, L. J. Bonales, J. Cobos and V. Timón, J. Phys. Chem. C, 2017, 121, 5994.

123 F. Colmenero, L. J. Bonales, J. Cobos and V. Timón, J. Phys. Chem. C, 2017, 121, 14507.

124 F. Colmenero, A. M. Fernández, J. Cobos and V. Timón, J. Phys. Chem. C, 2018, 122, 5268.

125 F. Colmenero, in Density Functional Theory, ed. D. Glossman-Mitnik, InTechOpen, London, 2018, ISBN: 978953-51-7020-4.

126 D. Langmuir, Aqueous Environmental Geochemistry, Prentice-Hall, New York, 1997, pp. 486-557.

127 I. Grenthe, J. Fuger, R. J. M. Konings, R. J. Lemire, A. B. Muller, C. Nguyen-Trung and H. Wanner, Chemical Thermodynamics of Uranium, Nuclear Energy Agency Organisation for Economic Co-Operation and Development, OECD, Issy-les-Moulineaux, France, 2004.

128 NEA Data Bank, Thermochemical Database (TDB), https:// www.oecd-nea.org/dbtdb/, accessed Nov. 22, 2019.

129 Thermo-Chimie database (Consortium Andra-Ondraf/Niras$R W M$ ), http://www.thermochimie-tdb.com/, accessed Nov. 22, 2019.

130 Rigaku Oxford Diffraction, CrysAlisCCD, CrysAlisRED and CrysAlis PRO. Oxford Diffraction Ltd, Yarnton, Oxfordshire, UK, 2019.

131 G. M. Sheldrick, Acta Crystallogr., 2015, 71, 3.

132 Crystallographic Computing System for Standard and Modulated Structures, Jana2006, http://jana.fzu.cz/, accessed Sept. 15, 2019.

133 S. J. Clark, M. D. Segall, C. J. Pickard, P. J. Hasnip, M. I. J. Probert, K. Refson and M. C. Payne, Z. Kristallogr., 2005, 220, 567.

134 MaterialsStudio, http://3dsbiovia.com/products/collaborative-science/biovia-materials-studio/, accessed Sept. 15, 2019.

135 J. P. Perdew, K. Burke and M. Ernzerhof, Phys. Rev. Lett., 1996, 77, 3865.

136 S. Grimme, J. Comput. Chem., 2006, 27, 1787.

137 M. C. Payne, M. P. Teter, D. C. Ailan, A. Arias and J. D. Joannopoulos, Rev. Mod. Phys., 1992, 64, 1045.

138 N. Troullier and J. L. Martins, Phys. Rev. B: Condens. Matter Mater. Phys., 1991, 43, 1993.

139 F. Colmenero, Characterization of Secondary Phases of Spent Nuclear Fuel under Final Geological Disposal Conditions: Experimental and Theoretical Studies, PhD Thesis, Universidad Autónoma de Madrid, 2017, DOI: 10.13140/RG.2.2.10526.43843.

140 F. Colmenero, L. J. Bonales, J. Cobos and V. Timón, Spectrochim. Acta, Part A, 2017, 174, 245.
141 F. Colmenero, L. J. Bonales, J. Cobos and V. Timón, J. Solid State Chem., 2017, 253, 249.

142 F. Colmenero, L. J. Bonales, J. Cobos and V. Timón, Clay Miner., 2018, 53, 377.

143 F. Colmenero, J. Cobos and V. Timón, Theor. Chem. Acc., 2019, 138, 43.

144 F. Colmenero, Appl. Sci., 2018, 8, 2281.

145 B. G. Pfrommer, M. Cote, M. S. G. Louie and M. L. Cohen, J. Comput. Phys., 1997, 131, 233.

146 H. J. Monkhorst and J. D. Pack, Phys. Rev. B: Solid State, 1976, 13, 5188.

147 R. T. Downs, K. L. Bartelmehs, G. V. Gibbs and M. B. Boisen, Am. Mineral., 1993, 78, 1104.

148 M. Coccioni, in Correlated Electrons: From Models to Materials Modeling and Simulation, ed. E. Pavarini, E. Koch, F. Anders and M. Jarrell, Forschungszentrum Jülich, Berlin, 2012, vol. 2, ch. 4.

149 S. L. Dudarev, D. Nguyen Manh and A. P. Sutton, Philos. Mag. B, 1997, 75, 613.

150 J. P. Crocombette, F. Jollet, L. T. Nga and T. Petit, Phys. Rev. B: Condens. Matter Mater. Phys., 2001, 64, 104107.

151 P. Nerikar, T. Watanabe, J. S. Tulenko, S. R. Phillpot and S. B. Sinnott, J. Nucl. Mater., 2009, 384, 61.

152 P. F. Weck, E. Kim, C. F. Jové-Colón and D. C. Sassani, Dalton Trans., 2013, 42, 4570.

153 D. A. Andersson, G. Baldinozzi, L. Desgranges, D. R. Conradson and S. D. Conradson, Inorg. Chem., 2013, 52, 2769.

154 G. Beridze and P. M. Kowalski, J. Phys. Chem. A, 2014, 118, 11797.

155 P. F. Weck and E. Kim, Dalton Trans., 2004, 43, 17191.

156 P. F. Weck, E. Kim and E. C. Buck, RSC Adv., 2015, 5, 79090.

157 P. F. Weck and E. Kim, J. Phys. Chem. C, 2016, 120, 16553.

158 D. C. Sassani, C. F. Jové-Colón, P. F. Weck, J. L. Jerden, K. E. Frey, T. Cruse, W. L. Ebert, E. C. Buck, R. S. Wittman, Fuel Cycle Research and Development Report FCRD-UFD-2013-000404, Sandia National Laboratories, Albuquerque, 2013.

159 T. M. Alam, Z. Liao, M. Nyman and J. Yates, J. Phys. Chem. C, 2016, 120, 10675.

160 N. Kalashnyk, D. L. Perry, F. Massuyeau and E. Faulques, J. Phys. Chem. C, 2018, 122, 7410.

161 S. Ostanin and P. Zeller, J. Phys.: Condens. Matter, 2007, 19, 246108.

162 S. Ostanin and P. Zeller, Phys. Rev. B: Condens. Matter Mater. Phys., 2007, 75, 073101.

163 R. Yu, J. Zhu and H. Ye, Comput. Phys. Commun., 2010, 181, 671.

164 J. F. Nye, Physical Properties of Crystals, Clarendon, Oxford, 1976.

165 F. Colmenero, Mater. Res. Express, 2019, 6, 045610; Mater. Res. Express, 2019, 6, 069401.

166 F. Colmenero, Phys. Chem. Chem. Phys., 2019, 21, 2673.

167 F. Colmenero, Mater. Lett., 2019, 245, 25.

168 F. Colmenero, Adv. Theory Simul., 2019, 2, 1900040.

169 F. Colmenero and V. Timón, J. Mater. Sci., 2020, 55, 218.

170 F. Birch, Phys. Rev., 1947, 71, 809. 
171 R. J. Angel, Rev. Mineral. Geochem., 2000, 41, 35.

172 EOSFIT 5.2 software; http://programming.ccp14.ac.uk/ccp/ web-mirrors/ross-angel/crystal/software.html, accessed Sept. 15, 2019.

173 A. Marmier, Z. A. D. Lethbridge, R. I. Walton, C. W. Smith, S. C. Parker and K. E. Evans, Comput. Phys. Commun., 2010, 181, 2102.

174 S. Baroni, S. de Gironcoli and A. Dal Corso, Rev. Mod. Phys., 2001, 73, 515.

175 X. Gonze and C. Lee, Phys. Rev. B: Condens. Matter Mater. Phys., 1997, 55, 10355.

176 K. Refson, P. R. Tulip and S. J. Clark, Phys. Rev. B: Condens. Matter Mater. Phys., 2006, 73, 155114.

177 W. J. Hehre, L. Radom, P. V. R. Schleyer and J. A. Pople, $A b$ Initio Molecular Orbital Theory, Wiley, New York, 1986.

178 C. Lee and X. Gonze, Phys. Rev. B: Condens. Matter Mater. Phys., 1995, 51, 8610.

179 A. A. Maradudin, E. M. Montroll, G. H. Weiss and I. P. Ivatova, Solid State Physics, ed. E. H. Ehrenreich, F. Seitz and D. Turnbull, Academic, New York, 2nd edn, 1971.

180 M. W. Chase, C. A. Davies, J. R. Downey, D. J. Frurip, R. A. McDonald and A. N. Syverud, J. Phys. Chem. Ref. Data, 1985, 14(suppl. 1), 1.

181 I. Barin, Thermochemical Data of Pure Substances, VCH, Weinheim, 3rd edn, 1995.

182 R. F. W. Bader, J. Hernández-Trujillo and F. CortésGuzman, J. Comput. Chem., 2006, 28, 4.

183 B. Lafuente, R. T. Downs, H. Yang and N. Stone, in Highlights in Mineralogical Crystallography, ed. T. Armbruster, R. M. Danisi and W. De Gruyter, Berlin, Germany, 2015, pp. 1-30.

184 RRUFF database, http://rruff.info/vandenbrandeite, Record R080114, accessed Sept. 15, 2019.

185 M. Born, Math. Proc. Cambridge Philos. Soc., 1940, 36, 160.

186 F. Mouhat and F. X. Coudert, Phys. Rev. B: Condens. Matter Mater. Phys., 2014, 90, 224104.
187 W. Voigt, Lehrbuch der Kristallphysik, Teubner, Leipzig, 1962.

188 A. Reuss, Z. Angew. Math. Mech., 1929, 9, 49.

189 R. Hill, Proc. Phys. Soc., London, Sect. A, 1952, 65, 349.

190 S. F. Pugh, Philos. Mag., 1954, 45, 823.

191 Y. Bouhadda, S. Djella, M. Bououdina, Y. Fenineche and Y. Boudouma, J. Alloys Compd., 2012, 534, 20.

192 H. Niu, P. Wei, Y. Sun, C. X. Chen, C. Franchini, D. Li and Y. Li Y, Appl. Phys. Lett., 2011, 99, 031901.

193 S. I. Ranganathan and M. Ostoja-Starzewski, Phys. Rev. Lett., 2008, 101, 055504.

194 F. Colmenero and V. Timon, J. Solid State Chem., 2018, 263, 131.

195 F. Colmenero, J. Phys. Chem. Solids, 2019, 125, 31.

196 F. Colmenero and R. Escribano, J. Phys. Chem. A, 2019, 123, 424.

197 Y. Tardy and R. M. Garrels, Geochim. Cosmochim. Acta, 1976, 41, 1051.

198 R. J. Finch, Mater. Res. Soc. Symp. Proc., 1997, 465, 1185.

199 S. B. Clark, R. C. Ewing and J. C. Schaumloffel, J. Alloys Compd., 1998, 271-273, 189.

200 F. Chen, R. C. Ewing and S. B. Clark, Am. Mineral., 1999, 84, 650.

201 B. George, L. P. Brown, C. H. Farmer, P. Buthod and F. S. Manning, Ind. Eng. Chem. Process Des. Dev., 1976, 15, 332.

202 W. R. Smith and R. W. Missen, Chemical Reaction Equilibrium Analysis: Theory and Algorithms, WileyInterscience, New York, 1982.

203 C. E. Harvie, J. P. Greenberg and J. H. Weare, Geochim. Cosmochim. Acta, 1987, 51, 1045.

204 M. H. A. Piro, Calphad, 2017, 58, 115.

205 K. A. Kubatko, D. Unruh and P. C. Burns, Mater. Res. Soc. Symp. Proc., 2006, 893, 423.

206 T. Z. Forbes, P. Horan, T. Devine, D. McInnis and P. C. Burns, Am. Mineral., 2011, 96, 202. 